\title{
Reconstruction of Planforms and Architecture of the Meandering Paleo-Channels-A Case Study of the 1st Member of Shanxi Formation, Central of Sulige Gas Field, Ordos Basin
}

\author{
Xue Yan ${ }^{1}$, Jinliang Zhang ${ }^{1, *}$, Yang $\mathrm{Li}^{2}$, Yan Zhang ${ }^{3, *}$ and Long Sun ${ }^{1}$ \\ 1 Faculty of Geographical Science, Beijing Normal University, Beijing 100875, China; \\ 201931051062@mail.bnu.edu.cn (X.Y.); longsun163@163.com (L.S.) \\ 2 Hubei Key Laboratory of Petroleum Geochemistry and Environment, Yangtze University, \\ Wuhan 430100, China; lyugly@163.com \\ 3 School of Geosciences, Yangtze University, Wuhan 430100, China \\ * Correspondence: jinliang@bnu.edu.cn (J.Z.); 201671301@yangtzeu.edu.cn (Y.Z.)
}

Citation: Yan, X.; Zhang, J.; Li, Y.; Zhang, Y.; Sun, L. Reconstruction of Planforms and Architecture of the Meandering Paleo-Channels-A Case Study of the 1st Member of Shanxi Formation, Central of Sulige Gas Field, Ordos Basin. Water 2022, 14, 477. https://doi.org/10.3390/ w14030477

Academic Editors: Achim A. Beylich, Yonggang Jia, J. Paul Liu and Chaoqi Zhu

Received: 28 September 2021 Accepted: 13 January 2022

Published: 5 February 2022

Publisher's Note: MDPI stays neutral with regard to jurisdictional claims in published maps and institutional affiliations.

Copyright: (c) 2022 by the authors. Licensee MDPI, Basel, Switzerland. This article is an open access article distributed under the terms and conditions of the Creative Commons Attribution (CC BY) license (https:// creativecommons.org/licenses/by/ $4.0 /)$.

\begin{abstract}
Although a large number of meandering rivers have been studied by means of modern sedimentation, instrument detection, numerical simulation, flume experiment and field outcrop, and a lot of achievements have been made, there are not many fine anatomical examples of deep buried ancient rivers, which is a situation that still needs to be improved. The main difficulties in the research of deep, ancient meandering rivers are the acquisition of data and the incompleteness of structure, which are both difficulties and challenges. Under the guidance of the modern meandering river fan sedimentary model and migration law, we established the scheme of meandering river geomorphology and structure. In the process of river migration, a variety of single migration models (expansion, contraction, rotation, and translation) and composite migration models can be distinguished. By analyzing the distribution structure characteristics of channel configuration elements in different migration modes, the coupled model of the meandering channel plane and profile structure is established by systematically constructing plane and profile combined with a three-dimensional channel configuration model. Based on the data of the dense well, taking the Shan 11 sublayer in the Su-x block of the Sulige gas field as an example, the reservoir structure of the deep, ancient meandering channel is dissected. In order to reconstruct the evolution of the deep, ancient channel and make it more consistent with the real laws of river migration and evolution, the morphological migration law of the modern river is applied to the ancient sedimentation, and the migration configuration is dissected by combining with the plane-profile structure coupled model. It further reveals the heterogeneity, the vertical distribution and the superposition form of the channel sand, and enriches the theory of the reservoir configuration of underground fluvial facies, all of which are significant for oil and gas exploration and development.
\end{abstract}

Keywords: Ordos Basin; meandering paleo-channel; migration model; reconstruction; Shanxi formation

\section{Introduction}

With continuous exploration and development, most of the domestic oilfields are in the stage of high water cut, and the focus of reservoir research controlled by rivers is shifted to the reservoir heterogeneity. The study of sedimentary facies cannot meet the requirements of fine development. The river reservoir configuration and fine sand body shape and distribution play an important role in guiding exploration and development. Therefore, based on the study of sedimentary facies, the study of river morphology will play a great role in solving the contradiction between exploration and production.

The research on fluvial facies has developed rapidly from the 1990s to the 21st century. There are five major research directions [1]: the coupling between the flow processes and 
near-bank geomorphic features; the co-evolution of meandering river sand; the experimental study between meandering rivers and material transportation; the morpho-dynamic evolution of meandering rivers and numerical simulation; the research of submarine meandering channels. The morphology and migration evolution of the meandering river are always a focus of research. River migration is affected by hydrology, hydrodynamics, sediment transport, geomorphology, climate, human and animal activities [1-4], which are not controlled by the river [5], and lead to the diversity of river morphology. Among the researchers, a large number of scholars have described the shape of the meandering river [6-14]. In the process of the meandering rivers' evolution, the channels are not all single model, but more a compound model, and most of them are asymmetric [8,15]. By field observation, satellite image, instrument detection, numerical simulation, etc., the morphology and evolution of the surface meandering river can be dissected, quantitatively analyzed and predicted [16-24]. In modern river deposition, a variety of migration modes are summarized. Schumm [6] proposed five types of channel morphology based on bending index, Daniel [7] determined five types of migration: expansion, rotation and translation by using sine curve, and Brice [9] proposed 16 models of meander morphology. The channel cut-off can be seen during the process of evolution [25-27], and chute and neck cutoffs are common. Migration patterns have been recognized and analyzed in modern sedimentary rock. These migration patterns include several planform migration modes: (1) symmetrical expansion migration (SEM): the length and curvature of the channel increase continuously, and the bend apex migrates transversely along the floodplain (Figure 1a); (2) upstream + rotation expansion migration (UREM): the length and curvature of the channel increase continuously, and the bend apex moves upstream of the floodplain (Figure 1b); (3) downstream + rotation expansion migration (DREM): the length and curvature of the channel increase continuously, and the bend apex moves downstream of the floodplain (Figure 1c); (4) symmetrical contraction migration (SCM): the curvature and amplitude decrease, and the bend apex migrates transversely along the floodplain (Figure 1e); (5) upstream + rotation contraction migration (URCM): the curvature and amplitude decrease, and the bend apex moves upstream of the floodplain (Figure 1f); (6) downstream + rotation contraction migration (DRCM): the curvature, and amplitude decrease, and the bend apex moves downstream of the floodplain (Figure 1g); (7) translation migration(TM): the channel sinuosity is constant, while the bend apex migrates parallel downstream (Figure 1d); (8) translation rotation migration (TRM): the bend apex moves towards the meander belt axis without straight line (Figure $1 \mathrm{~h})$. The authors $[8,28]$ show that the channel migrates downstream frequently. In the study of Okavango meandering river migration, the river is also dominated by downstream migration. In addition, these migration patterns are often combined (Figure 1i-1), which is consistent with the results of modern satellite images and aerial photos.

Despite vast amounts of research into modern rivers, with relatively mature and perfect theory, the migration model of paleochannel sediments cannot be well inferred and revealed due to the deep buried morphology and small outcrops $[29,30]$. At the same time, the literature related to its internal structure and development mechanism is relatively small, which also limits our understanding of paleochannel morphological changes [7,9,31-33]. Previous researchers used seismic, core and outcrop data to restore and reconstruct the paleochannel [30,34], but there were some limitations. Although there are some differences in the research methods between ancient and modern sediments, sediments adhere to similar hydrodynamic conditions in the process of migration. Based on the above research, the channel is not a single and symmetrical migration model. In continuous migration, there are not only multiple model conversions, but also the combination and superposition of migration of different stages in the plane, which control the lithology distribution and reservoir properties. Therefore, river migration is particularly important in the study of the fluvial reservoir. 

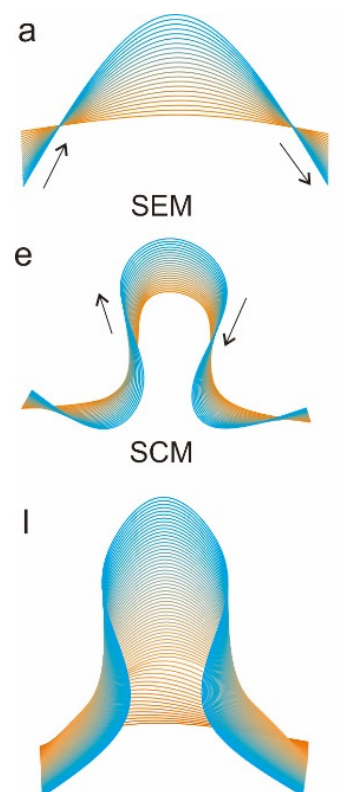

$\mathrm{SE}+\mathrm{CM}$

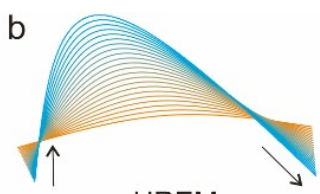

UREM

f

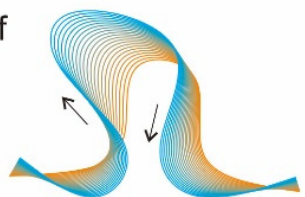

URCM

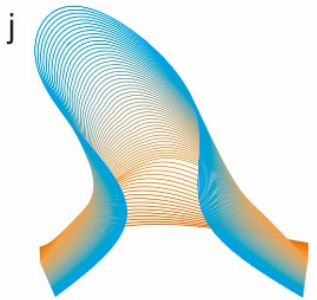

URE $+\mathrm{CM}$

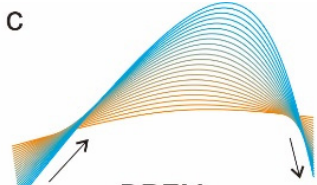

DREM

g

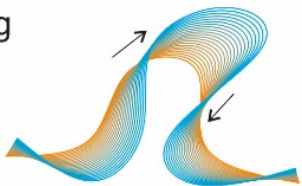

DRCM

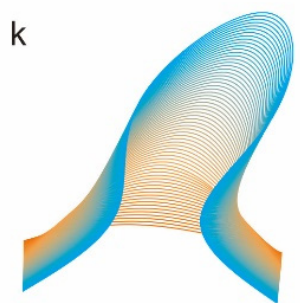

$\mathrm{DRE}+\mathrm{CM}$

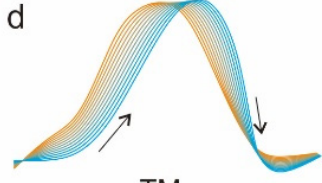

TM

h

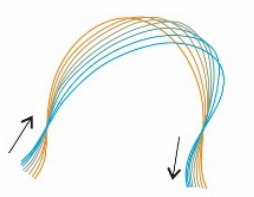

TRM

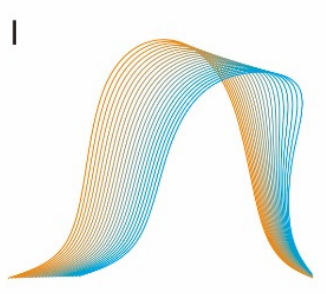

TR+EM

Figure 1. Typical planform migration modes, depicting the migration track of river channel. (a) symmetrical expansion migration; (b) upstream + rotation expansion migration; (c) downstream + rotation expansion migration; (d) translation migration; (e) symmetrical contraction migration; (f) upstream + rotation contraction migration; $(\mathrm{g})$ downstream + rotation contraction migration; $(\mathbf{h})$ translation rotation migration; (i) symmetrical expansion + contraction migration; (j) upstream rotation expansion + contraction migration; (k) downstream rotation expansion + contraction migration; (l) translation rotation + expansion migration.

Our predecessors have made a lot of significant achievements in reservoir configuration and the morphology of the meandering river, but the more detailed meandering river cases are rare, and now there are relatively few cases for the reconstruction of ancient channels. Therefore, "to the ancient theory of this", this is an important supplement to the study of ancient meandering rivers. There are eight single migration models and four compound migration models in the Okavango meandering river fan. The stratigraphic characteristics are connected with geomorphic dynamics based on the characteristics of the paleoenvironment. The dynamics of the meandering river is difficult to describe only by logging and core data. Based on the dense well pattern, the geomorphological migration law of modern rivers is applied to ancient sedimentation, and combined with the plane cross-sectional structure coupling model of the meandering channel to realize the reconstruction of the ancient channel, so this method is feasible and effective. In this study, there are three research goals: (1) To analyze the sedimentary characteristics and sandstone configuration on the horizontal and vertical profiles; (2) Combining the geomorphic features to associate it with the modern sedimentary model; (3) The sedimentary model is used to explain the distribution of three-dimensional facies. This study can reduce the deviation between the sedimentary structure and the evolution of the meandering river.

\section{Geologic Setting and Stratigraphy}

\subsection{Location of Study Area}

The Ordos Basin is a large interior subsiding basin formed during the Indosinian tectonic movement in the late Triassic period [35], located in the central and western part of the North China Craton. The basin is a secondary structural unit of the North China Craton, with stable subsidence, depression migration and torsion. It is also the second largest sedimentary basin in China. Its tectonic evolution can be divided into five stages: middle-late Paleozoic aulacogen stage, early Paleozoic shallow platform stage, late Paleozoic coastal plain stage, Mesozoic inland basin stage and Cenozoic peripheral 
fault depression stage [36]. After multistage evolution, the whole basin is composed of six tectonic units: Yimeng uplift, Western edge overthrust belt, Tianhuan depression, Yishan ramp, Jinxi flexural fold belt and Weibei uplift (Figure 2A) [37]. The present tectonic feature of the basin is an asymmetric rectangular basin with a gentle east flank and a narrow west flank (Figure 3). The Ordos Basin has huge reserves of gas, with 38 oil fields and 6 gas fields. The study area of this paper is located in the Sulige gas field (called Su-X), which is located in Suligemiao area, from Obogahan in Otokehouqi in the north to Wuqi County in the South, while it spans from Yulin City in the east and Etuoke Banner of Inner Mongolia Autonomous Region in the west.
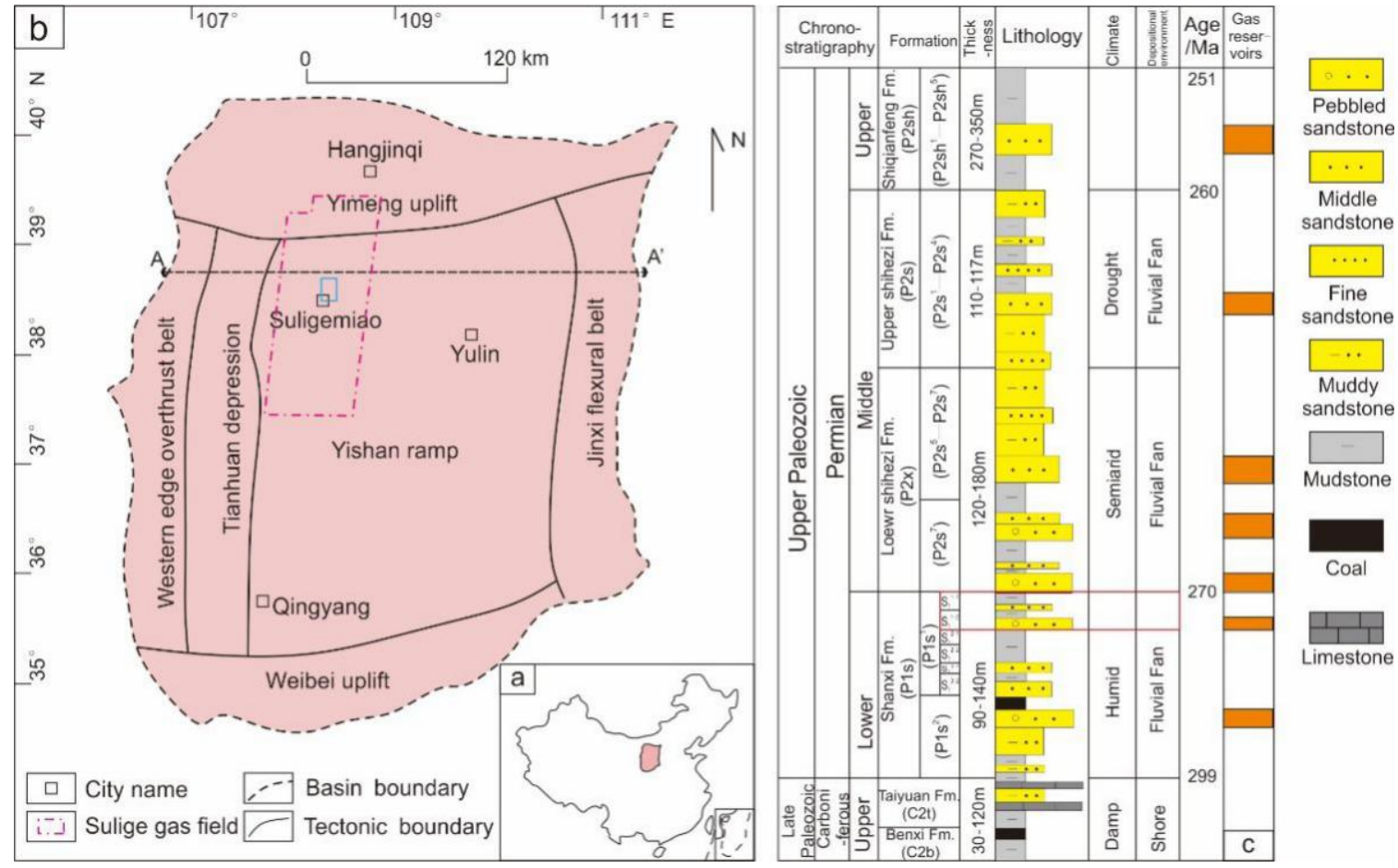

Figure 2. Location of Ordos Basin in China and Tectonic unit division of Ordos Basin $(\mathbf{a}, \mathbf{b})$. The red virtual frame in (b) indicates the location of Sulige gas field, and the blue box is the research area of this paper, called Su-X block; lithostratigraphy characteristics of Ordos Basin (c), the red frame indicates the monolayers of the study.

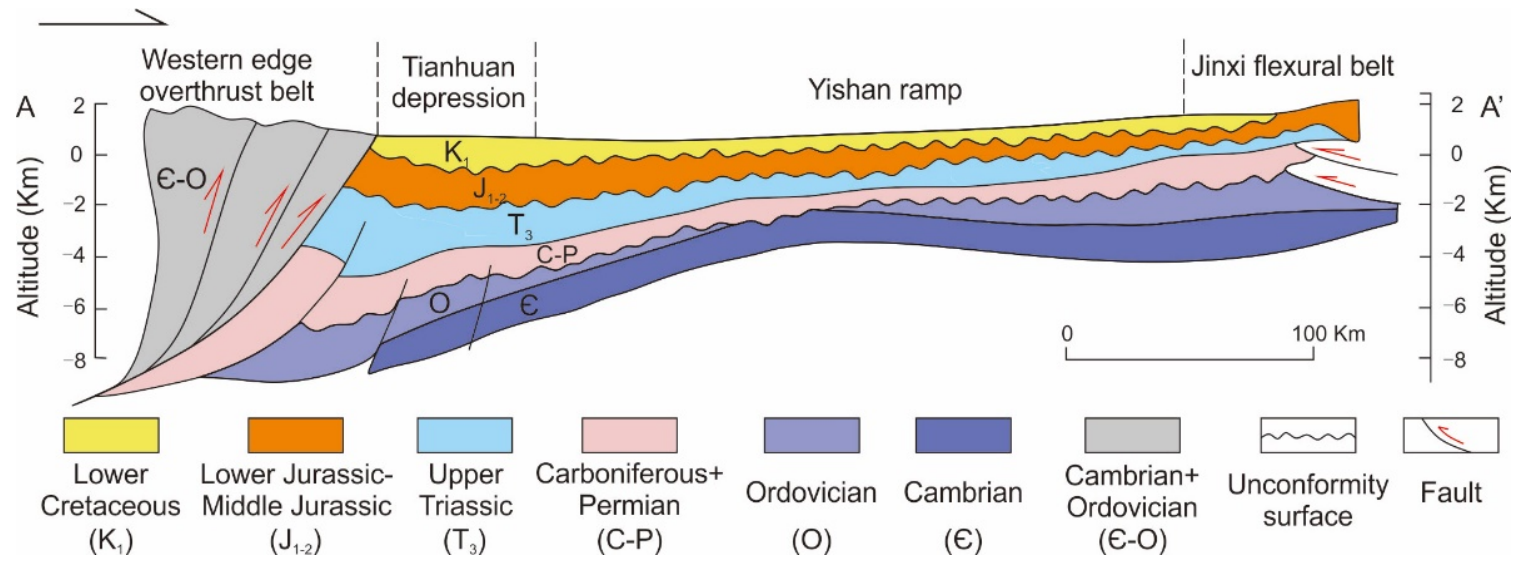

Figure 3. Typical stratigraphic profile of Ordos Basin 


\subsection{Stratigraphic Characteristics}

Stratigraphic development in the upper Paleozoic Permian of the Ordos Basin, including Shanxi Formation $\left(\mathrm{P}_{1} \mathrm{~s}\right)$, lower Shihezi Formation $\left(\mathrm{P}_{2} \mathrm{x}\right)$, upper Shihezi Formation $\left(\mathrm{P}_{2} \mathrm{~s}\right)$ and Shiqianfeng Formation $\left(\mathrm{P}_{2} \mathrm{sh}\right)$. The Shanxi Formation and Shihezi Formation is an important gas-bearing stratigraphic unit (Figure $2 b$ ). The $\mathrm{P}_{1} \mathrm{~s}$, with a bottom of "beichagou sandstone", is integrated on the Taiyuan formation. Its thickness is about $90 \sim 110 \mathrm{~m}$ and a slight thinning trend to the west. The clastic deposits are mainly from the Yimeng uplift in the late Paleozoic [38]. The Shanxi formation is a set of clastic deposits with coal. The lithology is mainly gray-white quartz sandstone and fine conglomerate, some lithic sandstone, intercalated with thin layers of siltstone, mudstone and coal, with plant fossils [35]. According to the characteristics of the deposition cycles and lithological composition, it can be subdivided into Shan $2\left(S_{2}\right)$ and Shan $1\left(S_{1}\right)$ from bottom to top. The thickness of $S_{1}$ is $40-50 \mathrm{~m}$, which is composed of three sublayers (including $\mathrm{S}_{1}{ }^{1}, \mathrm{~S}_{1}{ }^{2}, \mathrm{~S}_{1}{ }^{3}$, from top to bottom).

\subsection{Environment and Sedimentary Facies}

Since the late early Permian period (Shanxi Formation) was in the key period of sea-land conversion under the background of regression, the sedimentary background is still controversial. The sedimentary environment is mainly fluvial-lacustrine facies during the Permian period [39], while Shanxi Formation developed a shallow braided river delta dominated by fluvial and tide [40-43]. A meandering river delta developed in the Suligemiao area and north of the Ordos Basin [44,45]. The fossil assemblages in the Shanxi formation indicate a warm and humid climate. According to the analysis of mudstone and shale samples, the $\mathrm{Sr} / \mathrm{Cu}$ ratio is generally small and distributed intensively, and the mineral content of the kaolinite and Yimeng mixed layer in its clay minerals is high, which indicate that the Shanxi formation has a warm and humid climate. It is consistent with previous studies $[46,47]$. The author [35] described the lowstand systems tract in the model as comprising braided river deposits, the transgressive systems tract consisting mainly of fine-grained anastomosing river deposits, and meandering river deposits dominating in the highstand systems tract. The authors $[48,49]$ shared the view that the lowstand systems tract contains multistorey amalgamated sand-bodies and the sand-bodies in the transgressive and highstand systems tracts are more isolated. The Shanxi Formation in the Ordos Basin is characterized by different sedimentary facies due to the change of water level.

The genesis, channel type, channel transformation mode, properties and characteristics of the Okavango meandering river fan provided new enlightenment for the understanding of the sedimentary environment of a large, tight gas field. Different scholars have some disputes about the sedimentary background of the Shanxi formation. On the basis of previous studies, the coal thickness of the Shanxi formation is greater in the north of Wushenqi-Yulin, medium in Sulige area, and narrow in Yan'an-Qingyang [50]. The dark mudstone of the Sulige gas field is thick [51] and the plant fossil assemblage indicates a warm and humid climate. The coal and dark mudstone indicate the watery environment. To sum up, the wide swamp and wetland environment developed in the northern and center of the basin, while the sedimentary environment tends to arid in the south. This is similar to the Okavango meandering river fan. The distributary interchannel in the upper fan and middle fan store water through vegetation, and broad wetlands and swamps developed which provided the conditions for coal. The lower fan grows sandy substrate, and the surface water is seasonal, with less coal (Figure 4). The difference is that the Okavango meandering river fan is a single provenance sedimentary system, while the Shanxi Formation in the Ordos Basin is a multiple-sediment-source system (Figure 5). Although the general climate of the two epochs can be assumed to be similar, no data can be obtained about the properties of the river flow that led the formation and migration of the point bars. 


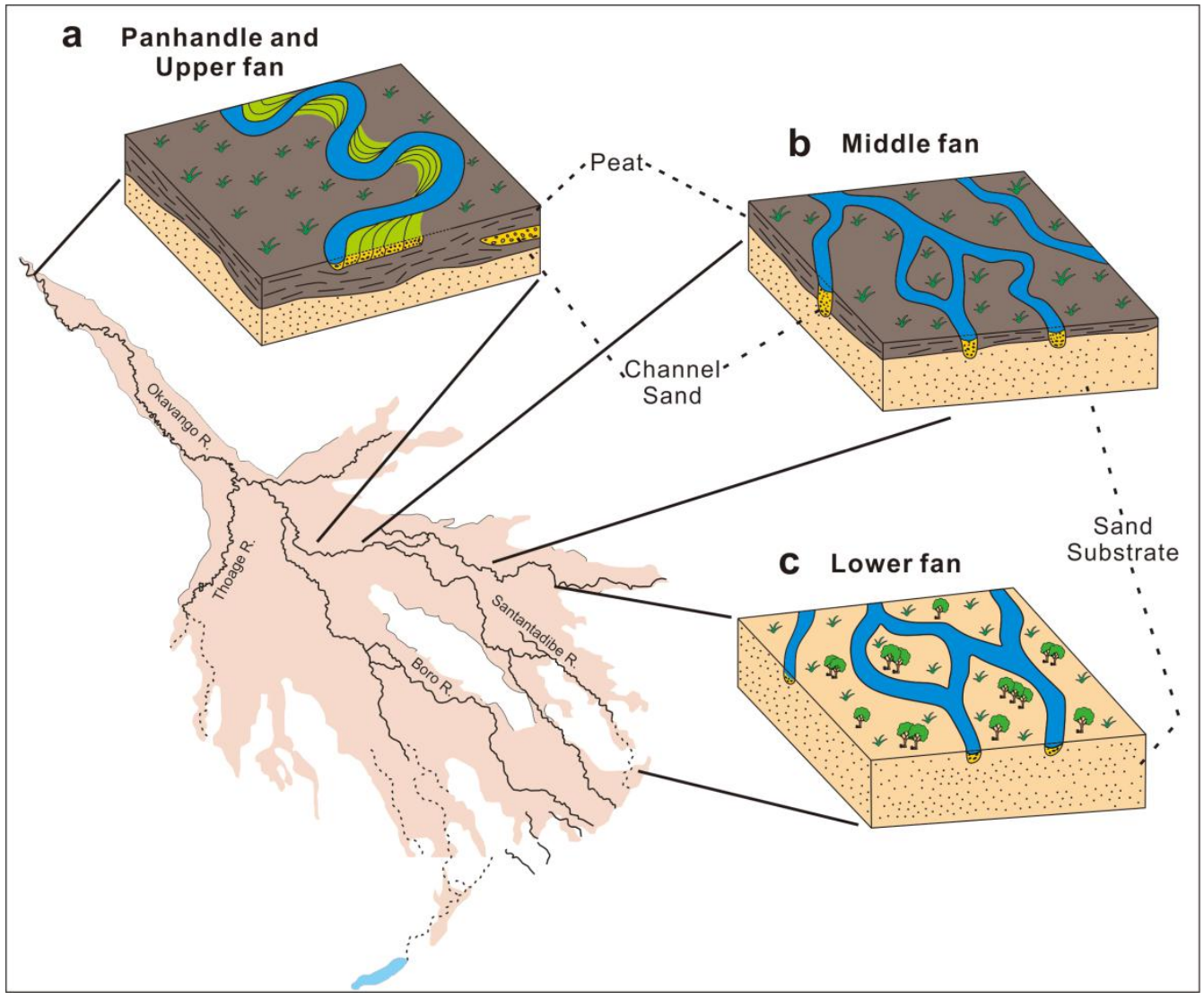

Figure 4. Schematic diagram showing the varying style of river channel and overbank sediments in (a) the panhandle and upper fan, (b) middle fan, and (c) lower fan sub-environments of the Okavango Fan (modified from Stanistreet and McCarthy, 1993).

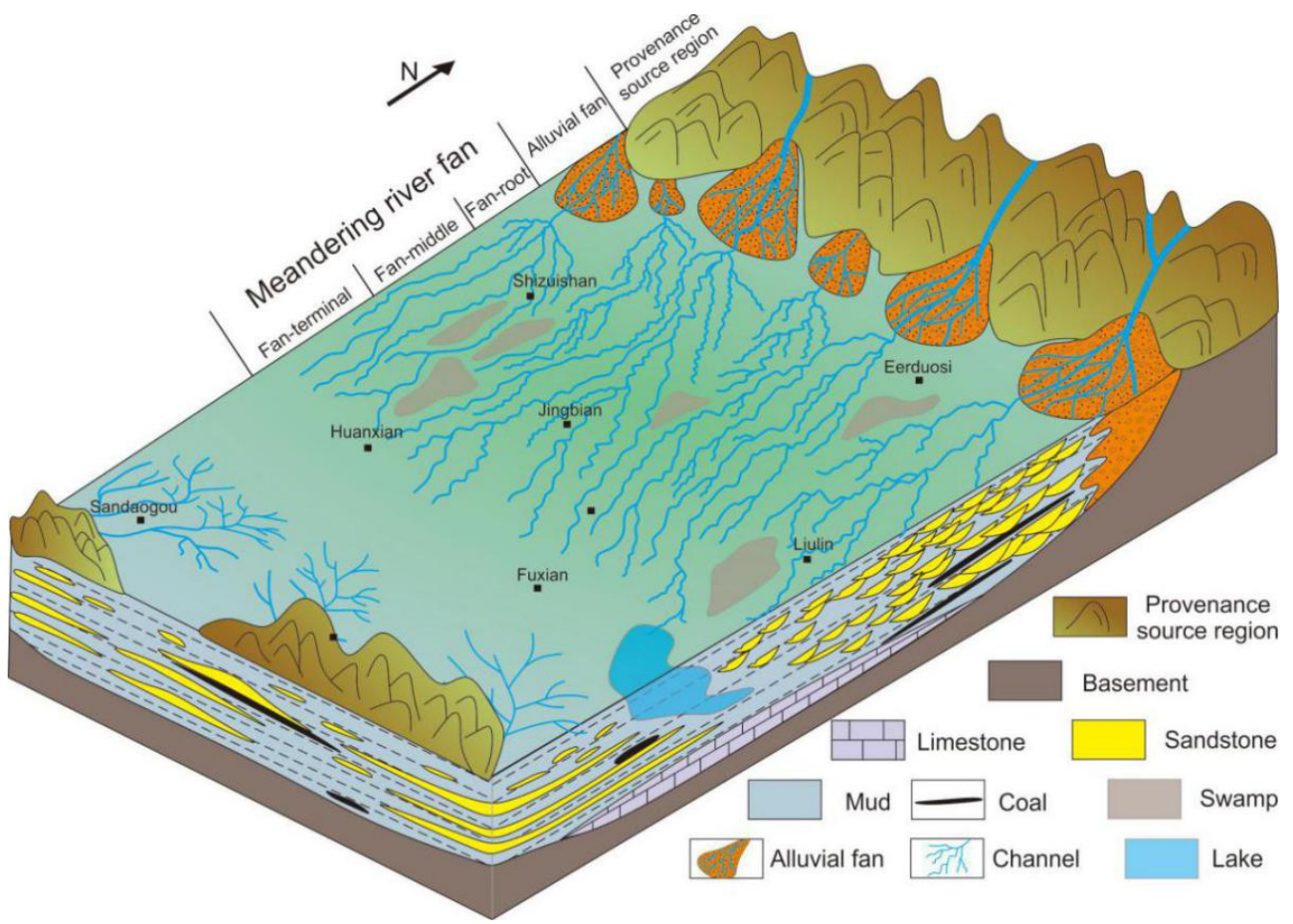

Figure 5. Depositional model of Shanxi Formation in the Ordos Basin. 
In the north of the Ordos Basin, typical tight sandstone reservoirs developed, with strong source supply, which are distributed continuously in the plane, overlapped in the vertical, and the sand bodies extend in the north-south direction. The Su-X block of the Sulige gas field is located in the middle fan. The meandering river fan system is mainly developed in the Shan $1^{1}$ layer. The sedimentary microfacies are composed of branch channel, crevasse splay, floodplain and swamp. The channel belt becomes more complex after bifurcation. With the increase of channel curvature, the channel belt is superimposed continuously. The point bar is characterized with fining-upwards normal cycle sandstone, and the floodplain area is dominated by mudstone, with coal and root. The channel is characterized by a mixed deposition of bed load and suspended load, and the erosion interface is common.

\section{Data and Methods}

\subsection{Data Sources}

In this paper, the sublayer of Shan $1^{1}\left(\right.$ Called $\left._{S_{1}}{ }^{1}\right)$, member 1 of Permian Shanxi Formation in Su-X block is selected as the main research object. The main sedimentary environment of $S_{1}^{1}$ is river deposition, which is representative of a continental river. Data from 99 wells were collected from cooperation project with the Changqing Oilfield Corp, among which 14 transverse profiles and 9 longitudinal profiles were reconstructed (Figure 6). For each profile, data about lithology and core were collected. By integrating the structure of core, lithological sequences, small layer correlation and unconformity interface of scour data with previous studies, the above-mentioned profiles were interpreted and identified for a single meandering channel, step by step with points, lines and surfaces. The scale and law of the point bar with dense well pattern were statistically extrapolated to the sparse well pattern, and the ancient meandering channel was reconstructed through multiple profile. This paper focuses on the detailed description of six profiles (Figure 6, blue line) to explain the evolution process of the meandering zone.

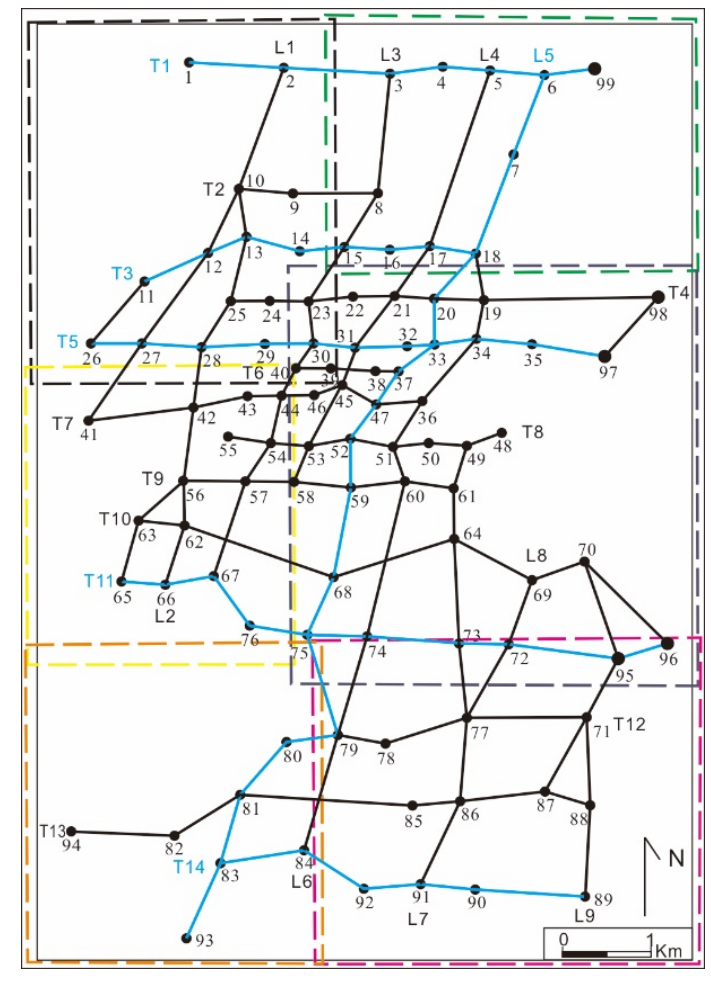

Figure 6. Location of dense drilling holes and profile in the Su-X block Sulige gas field of Ordos Basin, China; Six profiles (blue line) are described in detail. It is divided into six zones by virtual frame, the green frame is zone 1, black frame is zone 2, yellow frame is zone 3, gray frame is zone 4, red frame is zone 5 and orange frame is zone 6 . 


\subsection{Method}

The research on oil and gas accumulation in petroliferous basins is of great significance to oil and gas exploration. In addition to oil source correlation, basin simulation and other technologies [52,53], it is also particularly important to carry out the study of modern paleontology. Herein, the descriptive sedimentological term for meander channel processes is used [54,55], while the hierarchical descriptive small-scale bedding structure is derived from Collinson et al [56]. On this basis, the architecture of the meander belt can be recognized along the longitudinal meander belt instead of transverse, which is difficult to identify in the vertical direction [57]. In particular, understanding of the ancient meandering channel is limited by the different migration patterns superimposed on the plane and deeply buried. Through core observation and single well facies analysis, sedimentary facies markers, lithologic characteristics and logging response, the well's stratigraphic framework was established in the study area. First, research of a single well. The logging and core were used to identify the sequence, and the lithology and sedimentary microfacies by establishing a sequence stratigraphic framework. Second, the combination of channel sand bodies based on the well connection profile and judging the connectivity of the sandstone by production data. Third, through the plane and vertical identification of single sandstone and the connection relationship between sandstones, the distribution of ancient channel was described in detail. Fourth, restoring the channel evolution by using the combination of plane and section. According to the data of the layers and sand in the well, the lithofacies paleogeographic characteristics were analyzed, the sedimentary model was established, which predicted the possible horizontal and vertical distribution of sedimentary facies. Due to the influence of well pattern density, the prediction result is uncertain, and the result of dense well pattern area is closer to the actual situation than that of sparse well pattern area. The density of the wells and the data available from the geophysical logs were insufficient to reconstruct the external geometries and internal sedimentological characteristics of the point bars that are now buried at more than $3000 \mathrm{~m}$ depth. Consequently, the reconstruction provided in the following chapters was obtained by adopting the same pattern reconstructed from the modern Ordos Basin analog, while being aware that this approach could be affected by uncertainties.

\subsection{Data Acquisition}

Combining the characteristics of core and logging curve, it was observed that the petroelectric characteristics of the different lithologies were different. So, they have different logging characteristics in different sedimentary microfacies. The distribution of sand and sedimentary facies was analyzed mainly by using the amplitude, shape, top-bottom contact relationship and smoothness of GR and AC curve (Figure 7). In the GR curve, the point bar was characterized by box or bell shape. The GR value was relatively small, mostly less than 50API. The thickness of sand was 5-10 m; crevasse splay was characterized by a finger shape. The GR value was low-medium value, mostly less than 70API. The thickness of sand was less than $3 \mathrm{~m}$; subchannel was characterized by irregular box shape. The GR value was around 50API, thickness of sand between $3 \mathrm{~m}$ and $5 \mathrm{~m}$; main channel was characterized by a bell shape. The values gradually changed from bottom to top, with low bottom and high top, with the bottom value less than 50 API. Thickness of sand was 5-10 m; abandoned channel was characterized by cap shape, the GR value of bottom was less than 50 API, up to 100 API. The thickness was usually less than $3 \mathrm{~m}$. The meandering channel is dominated by coarse-gravelly coarse sandstone and medium-fine sandstone, forming a normal gradation. The GR curve was toothed, box shaped and bell shaped with low value. The negative abnormal amplitude of AC curve was large; The flood plain is dominated by mudstone, and the GR curve was a high value, toothed box, with low amplitude of AC curve. By analyzing the four identification marks of channel sand, elevation difference, thickness difference and abandoned channel, a single channel can be identified [58,59]. The vertical stage of the river channel is based on the sedimentary section, which is mainly identified by the characteristics of mud interlayer, calcareous interlayer and logging curve mutation. 
The mud interlayer had the high GR value, which was generally higher than 150API; AC was high value, usually greater than $240 \mu \mathrm{s} / \mathrm{m}$. Argillaceous sedimentary discontinuities are often unstable laterally due to channel undercutting; GR of calcareous interlayer was low, with a low value of AC. Logging curve mutation indicates the lithological changes.

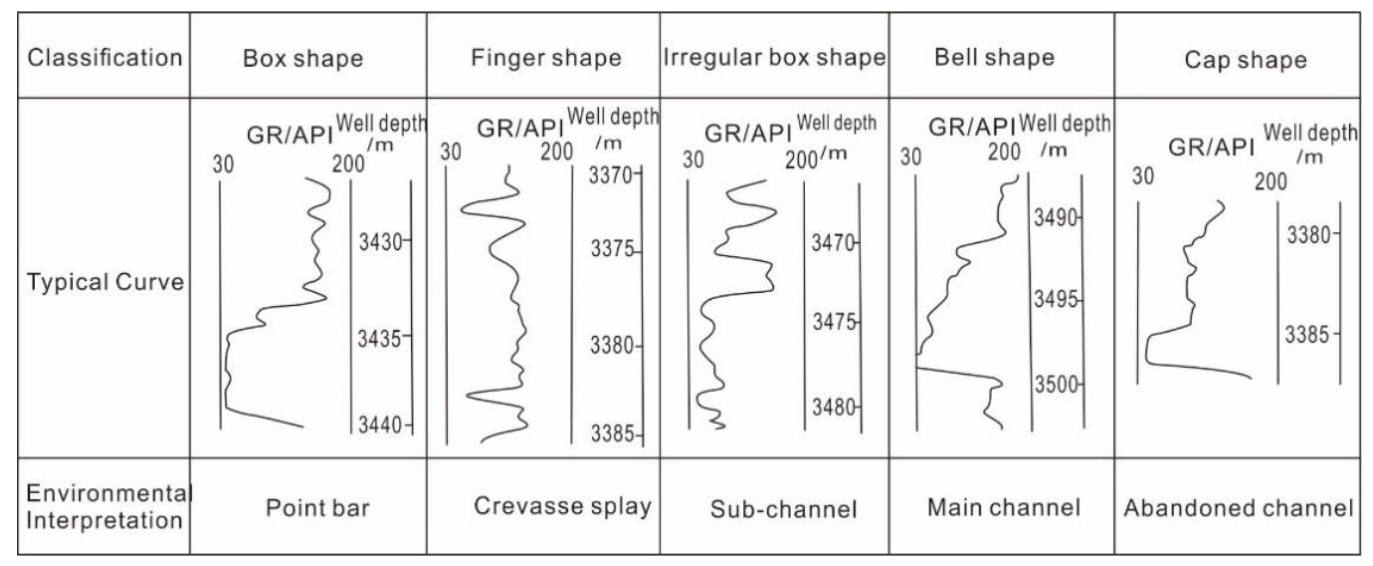

Figure 7. Logging characteristics of different sedimentary microfacies.

\section{Results}

\subsection{Lithology and Well-Logging Characteristics}

In the study area, well 10 was selected as the standard well for the lithofacies analysis of $S_{1}{ }^{1}$. The deposition of $S_{1}$ is mainly composed of sandstone, pebbly sandstone and mudstone (Figure 8). The core depth of well 10 is 3314-3350 $\mathrm{m}$ (Figure 9), and the 3314-3329 $\mathrm{m}$ is the $S_{1}{ }^{1}$ sub layer. Parallel bedding, oblique bedding, cross bedding and mud gravel are developed, which developed an abrupt erosion surface at the bottom and developed a rare detention deposit. It is a typical point bar with obvious normal gradation and approximate box shape of GR curve. Thick mudstone and sandy mudstone are developed at the top, with horizontal bedding and sand bedding, which indicate fluviatile floodplain deposition. According to the lithology mutation, the scouring surface, grading, sand correlation mode and lithology combination, the $S_{1}{ }^{1}$ sublayer of all wells was subdivided and compared, and the two stages of river could be identified. In order to realize the river's evolution and reconstruction, the $S_{1}{ }^{1}$ sublayer was subdivided into two monolayers.
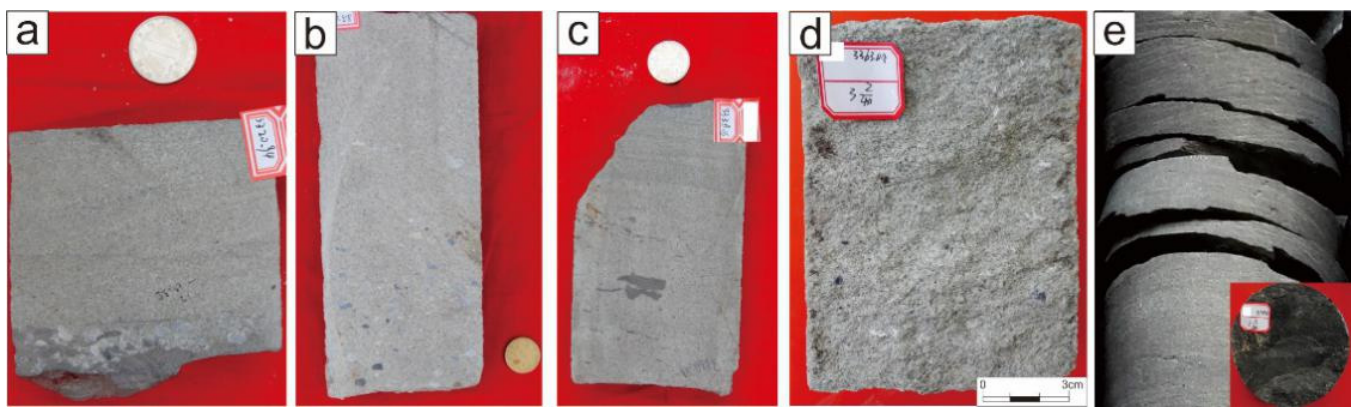

Figure 8. Lithologic characteristics in study area. (a) Well 94, erosion surface, $3320.94 \mathrm{~m}$; (b) well 82, pebbly sandstone, $3330.58 \mathrm{~m}$; (c) well 64, parallel bedding, $3338.16 \mathrm{~m}$; (d) well 8, sandstone, $3363.04 \mathrm{~m}$; (e) well 74, mud, $3358.03 \mathrm{~m}$. 


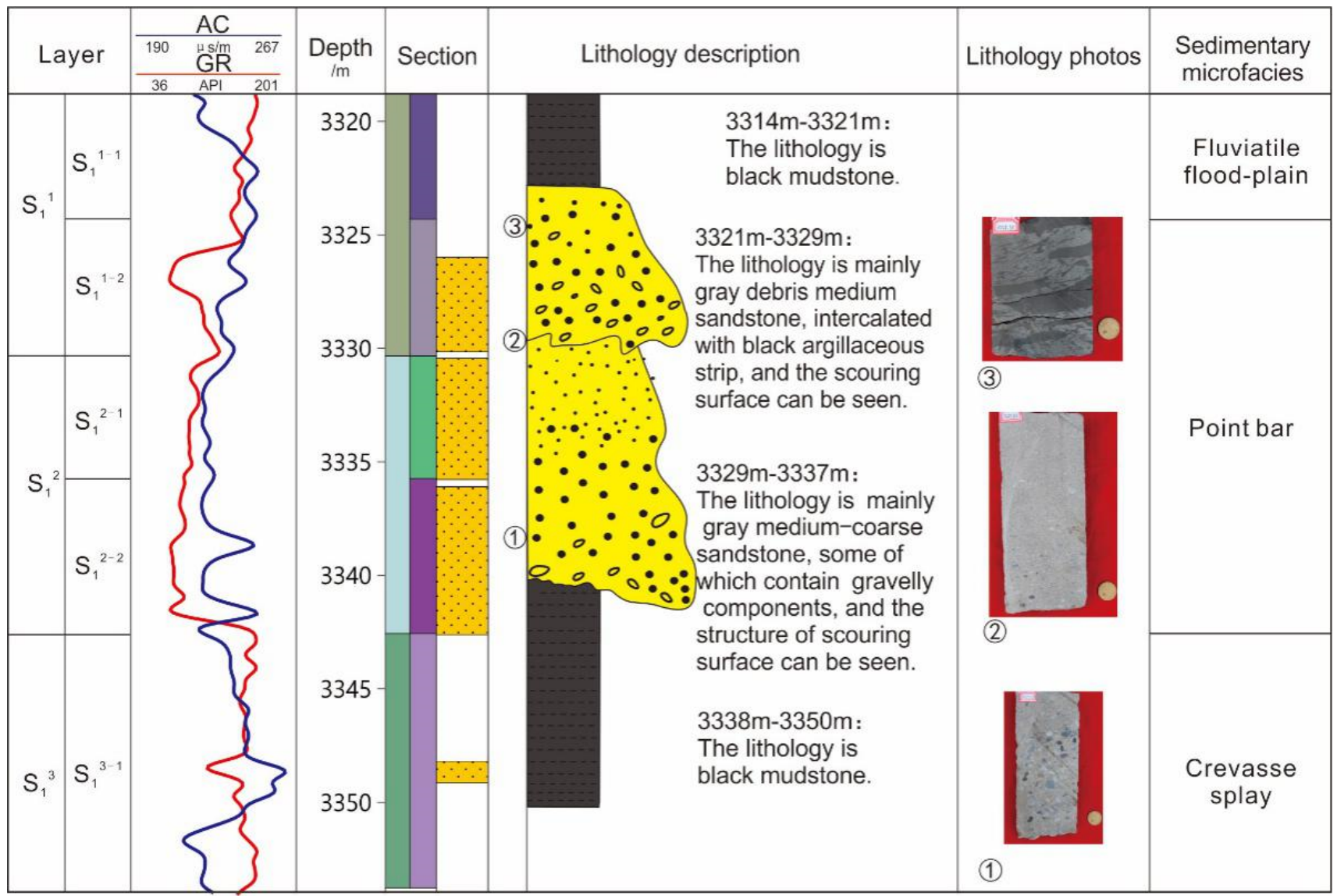

Figure 9. Core characterization and logging curve characteristics of well 10.

By observing the logging curve and core, the Su-X block is mainly formed in a meandering river, and the sedimentary microfacies include a branch channel, crevasse splay, floodplain and swamp (Figure 10), which are consistent with previous studies. The logging curves of the different sedimentary microfacies were obviously different in shape, grading, thickness and amplitude. An abandoned channel is an important signal to identify the boundary of a single channel. Based on amplitude and curve shape, its logging curve can be divided into two patterns: gradual transition interfaces and sudden transition interfaces. The sudden transition interfaces are abandoned at high energy, while the gradual transition interfaces are abandoned at low energy. There are multistage scour and superposition in the point bar, and the logging curves are mainly box-shaped, bell-box shaped and combinedbell shaped; The crevasse splay is the sediment overflowing inside the riverbed during the flood period, which is deposited outside the river channel and has sudden transition interfaces with the underlying floodplain, with finger-shaped logging curves. The flood plain is formed by the vertical aggradation of flood on the broad plain outside the riverbed. The lithology is mainly mudstone and argillaceous siltstone, with less sandstone. The logging curve is straight or low amplitude dentate. 


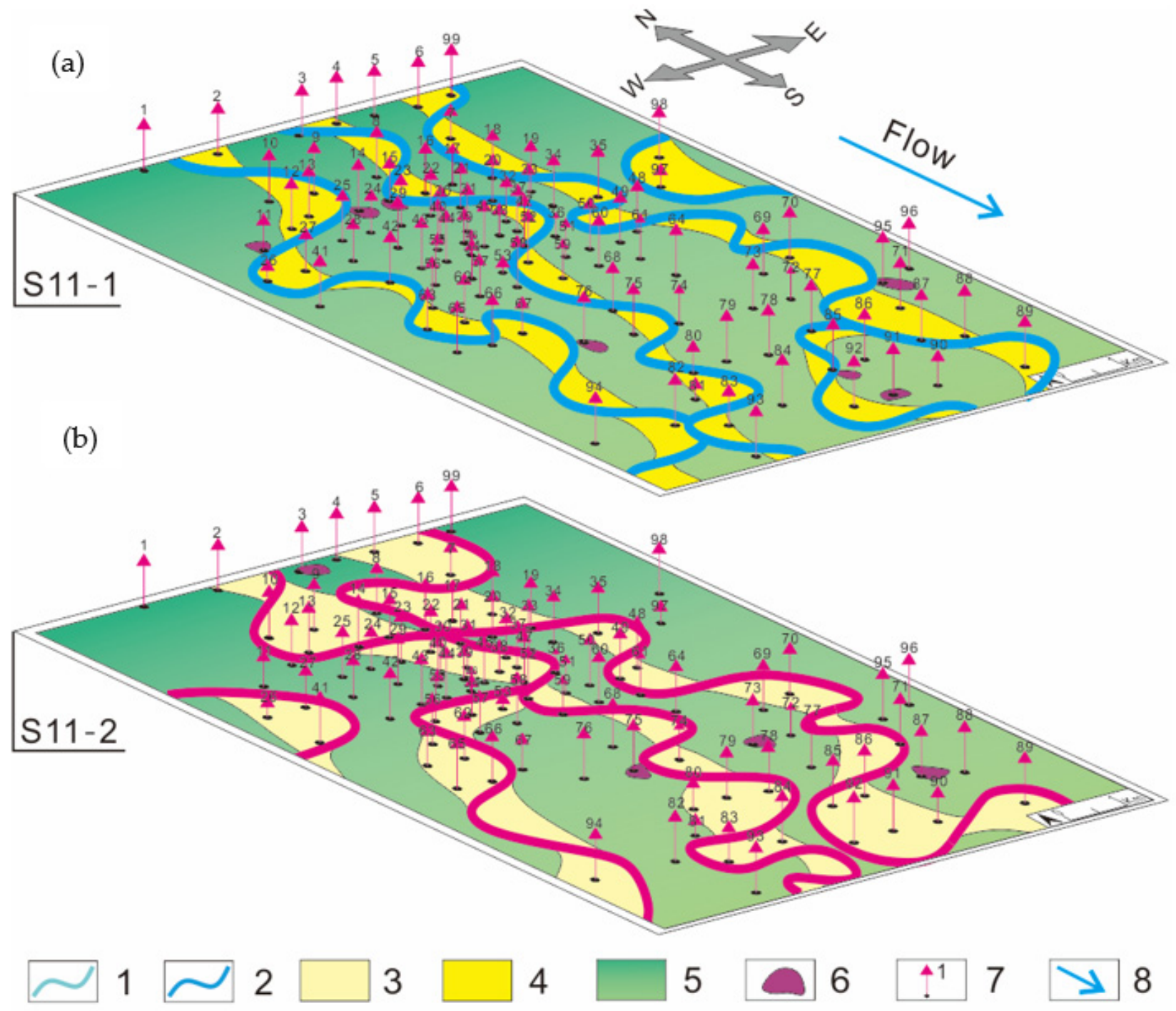

1. Shan11-1 channel; 2. Shan11-2 channel; 3. Shan11-1 point bar; 4. Shan11-2 point bar;
5. Floodplain;
6. Crevasse splay;
7. Well boreholes;
8. Flow direction

Figure 10. Plane distribution of sedimentary microfacies of $\mathrm{S}_{1}{ }^{1}$ sublayer in $\mathrm{Su}-\mathrm{X}$ block of Ordos Basin, (a) is $\mathrm{S}_{1}{ }^{1-1}$ monolayer, (b) is $\mathrm{S}_{1}{ }^{1-2}$ monolayer, showing the changes of sedimentary microfacies of two monolayers.

\subsection{Coupled Characteristics of Channel Plane and Profile}

Much inspiration has been obtained from the study of the sedimentary facies of the Okavango meandering river fan, as mentioned in Section 2.3 (Figure 11). It also indicates that the member of $S_{1}$ in Ordos Basin has similar sedimentary environment characteristics. Therefore, the river migration also follows similar hydrodynamic conditions, and the migration mode is shown in Figure 1. In the channel of $S_{1}$, the channel is vertically superimposed and transformed by different architectural elements, and a similar sequence is generated repeatedly. Meanwhile, the different migration types show different characteristics on the profile. The focus is the point bar. Due to the hydrodynamic force differences, upstream waterpower is stronger than downstream, as a result, the incision extent is deeper in the upstream leading to the development of a steeper dipping angle [30,57]. 


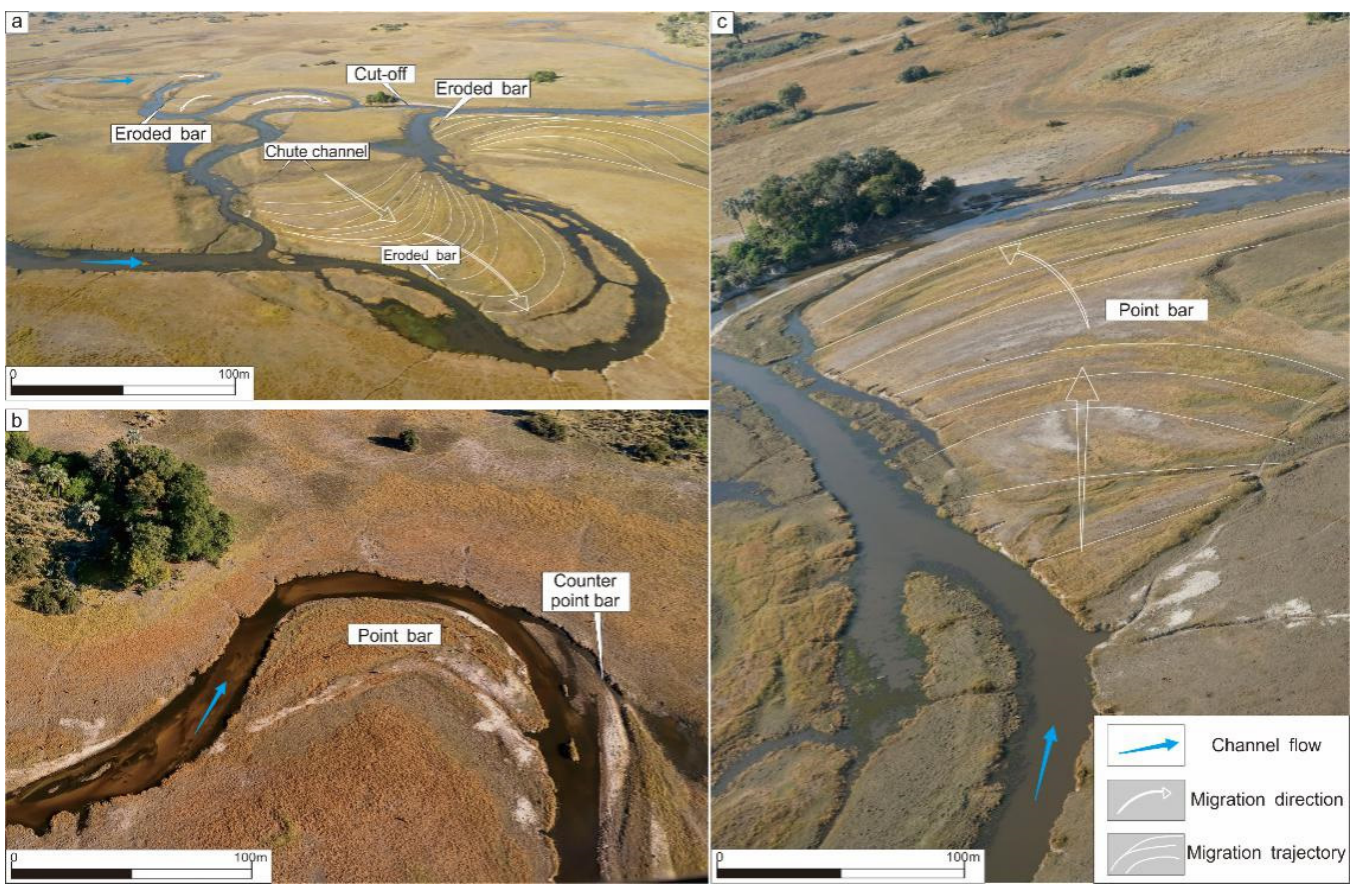

Figure 11. The river of the Okavango meandering river fan shows the geomorphic features of the meandering river. (a) Meandering with cut-off, eroded bars and chute channel; (b) Meandering with point bar and counter point bar; (c) Meandering with compound point bar.

In the above-mentioned eight single models, there are certain spatial variations in the profile: (1) SEM shows that the dipping angle decreases away from the meander belt axis (A-A' profile). In contrast, the upstream bar and downstream bar are symmetrical, and the dipping angle decreases parallel to the longitudinal meander belt axis (B-B' profile) (Figure 12a); (2) UREM shows that the dipping angle decreases and then increases to the longitudinal meander belt axis (A-A' profile) and the dipping angle of the upstream bar is greater than the downstream bar (B-B' profile) (Figure 12b); (3) DREM shows that the dipping angle decreases away from the meander belt axis (A-A' profile). The characteristic of the B-B' profile is contrary to UREM (Figure 12c); (4) SCM shows the dipping angle increases away from the meander belt axis (A- $\mathrm{A}^{\prime}$ profile). In contrast, the upstream bar and downstream bar are symmetrical (B-B' profile) (Figure 12e); (5) URCM shows that the dipping angle increases repeatedly to the longitudinal meander belt axis(A- $\mathrm{A}^{\prime}$ profile) and the dipping angle of upstream bar is greater than the downstream bar (B- $\mathrm{B}^{\prime}$ profile) (Figure 12f); (6) DRCM shows that the dipping angle increases repeatedly to the longitudinal meander belt axis (A-A' profile) and the dipping angle of upstream bar is less than the downstream bar (B-B' profile) (Figure 12g); (7) TM keeps the dipping angle stable in the $\mathrm{B}-\mathrm{B}^{\prime}$ profile, rather, the transverse dipping angle decreases in the A-A' profile (Figure $12 \mathrm{~d}$ ); (8) TRM gives a similar change rule as well as translation mode in the A-A' profile, thus, the dipping angles are divided into two parts to decrease in the B-B' profile, respectively, (Figure 12h).

To sum up, in the process of expansion, the transverse dipping angle increases slowly from inside to outside, while in the process of contraction, it increases rapidly; In the upstream rotation model, the vertical dipping angle of the upstream bar is larger than the downstream bar, but it is the opposite in the downstream rotation model.

In the paleo-sedimentary environment, the migration pattern of channels can be identified by the bedding dipping angle and migration direction of the bend apex. In compound migration, there are more than two single patterns, and the sediment on the sections overlap each other. In the expansion model, the upstream bar, central bar and downstream bar are well preserved. The upstream bar and central bar in the downstream model are poorly preserved, while the downstream bar in the upstream model is poorly 
preserved (Figure 13a). and the upstream bar in the translation model is not well preserved due to erosion (Figure 13b,c).
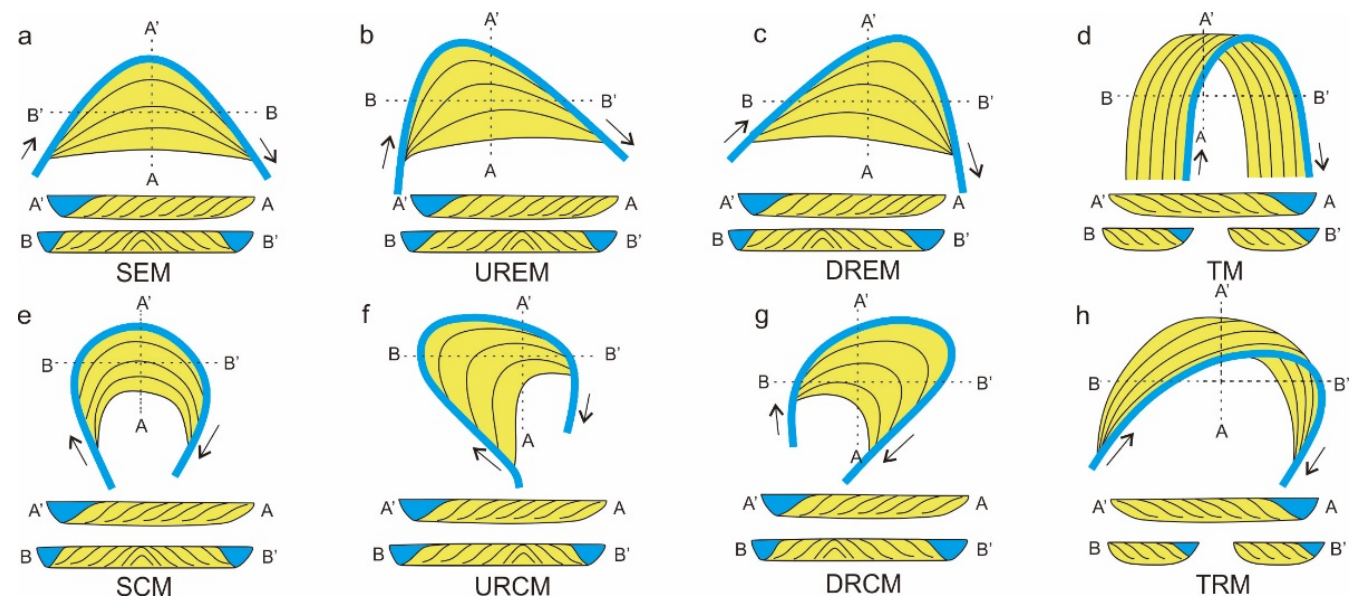

Figure 12. Stratigraphic sequence of single planform modes, $(\mathbf{a}-\mathbf{h})$ similar to that in Figure 1.

a
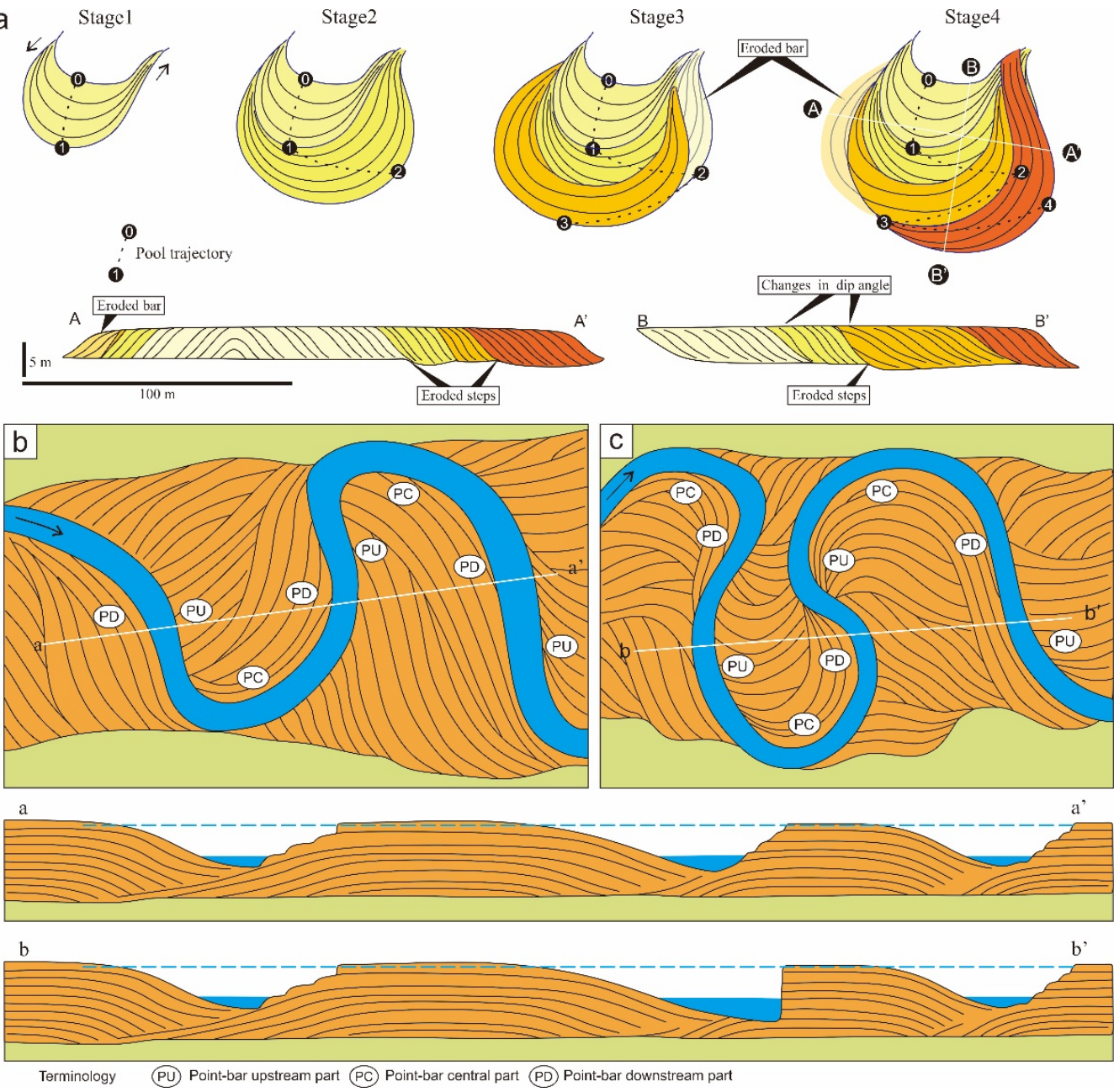

Figure 13. Cross section of composite model, highlighting the main structural factors of the migration and transformation of the meandering channel: (a) the asymmetric point bar of compound model, showing the planform evolution and internal architecture of the expanding four stages of pool zone migration [30]; (b) translation and (c) translation with rotation [57]. 
The block mainly develops a channel and floodplain, such as channel filling, point bar, etc. According to the well pattern data, the superimposition and erosion of the multistage channel is obvious. According to well data, the superimposition and erosion of the multistage channel is obvious. In the $\mathrm{S}_{1}{ }^{1}$ sublayer of the Su-X block, the channel was constantly changing and straightening, which limits the preservation of floodplain sediments. In contrast, the floodplain of the overlying strata is better preserved.

\subsection{Reconstruction of Meandering Paleochannels}

The migration model of modern rivers is applied to the restoration of ancient rivers. While it may be straightforward to observe the differences between the ancient sediments and the modern river sediments, it is difficult to directly apply modern sedimentary mesoscale parameters to the paleoenvironment [18]. Moreover, because the formation is deeply buried underground, it is impossible to measure the dip angle of lateral accumulation, and the representation of lateral accumulation belongs to qualitative inference. In the well-drain direction, the boundary is determined according to the logging data, the core and sand body distribution. Due to strong transformation by a later river, the exposure of the point bar is incomplete, and the research focuses on the $S_{1}{ }^{1-1}$ monolayer. Moreover, in order to achieve accurate migration structure interpretation and analysis, $\mathrm{Su}-\mathrm{X}$ is divided into six areas. Six configuration sections are mainly described. L5 (longitudinal profiles) is northeast-southwest strike, nearly parallel to the source direction, and T1, T3, T5, T11 and T14 (transverse profiles) are vertical to the source direction.

Zone 1: There are two meandering river belts in zone 1. Five wells meet the right meandering river belt (wells 6, 7, 18, 99) and six wells meet the left meandering river belt (wells $4,15,16$ ). The sand of wells 6 and 99 (Bend a) is well developed and belongs to the point bar. The sand is more developed in the later sand of well 99. Combined with the hydrodynamic characteristics, the channel migrates from well 6 to well 99. In wells 7 and 18 (Bend $b$ ), the early sand developed, while the later sand did not develop (abandoned channel), and wells 7 and 18 changed from a lateral accumulation point bar to abandoned channel; combined with the perforation data, the point bars are not connected. The results of anatomy indicate that Bends a and $\mathrm{b}$ migrate with symmetrical expansion, while the apex (pool zone) migrates transversely away from the channel belt axis, as shown in the Figures 14 and 15.

The sand formed in the early stage of well 3 and then turned into an abandoned channel, indicating that the channel migrated; In well 15 (Bend C), the early sand is not developed, and thin sand is developed in the late stage.

In well 16, the early sand is developed, and the later sand is not developed, which indicates that the channel moved from well 16 to well 15; combined with the configuration profile characteristics, Bend c developed symmetrical expansion structure, and the migration process of channel is shown in Figure 16.

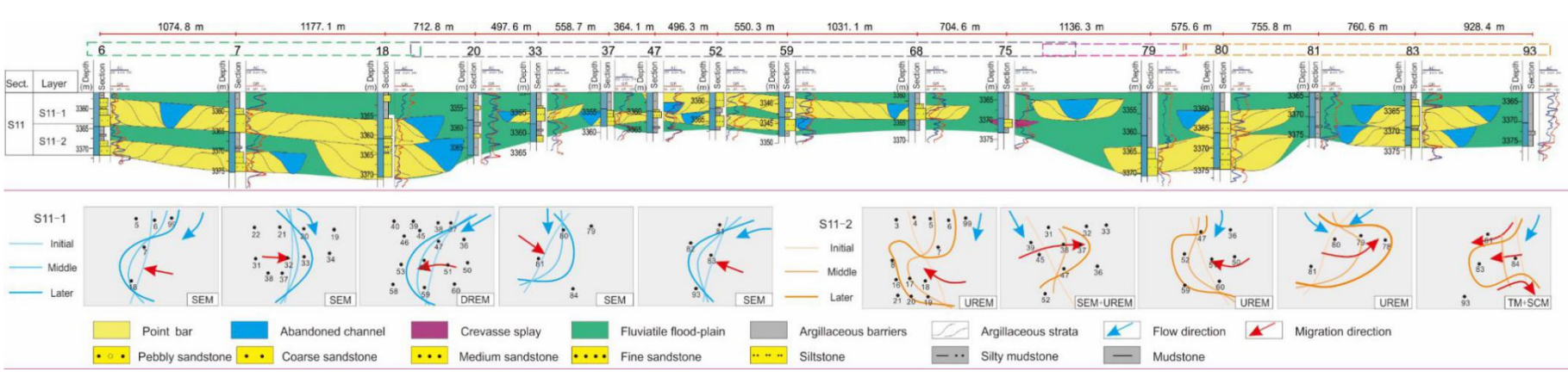

Figure 14. Profile L5 of comprehensive analysis including evolution model of meander bend-based multiple connected core wells which are collected from database in $S_{1}{ }^{1}$ sublayer of Su-X block, Sulige gas field, Ordos Basin, China: migration areas Z1 (green frame), Z4 (gray frame), Z6 (orange frame). 


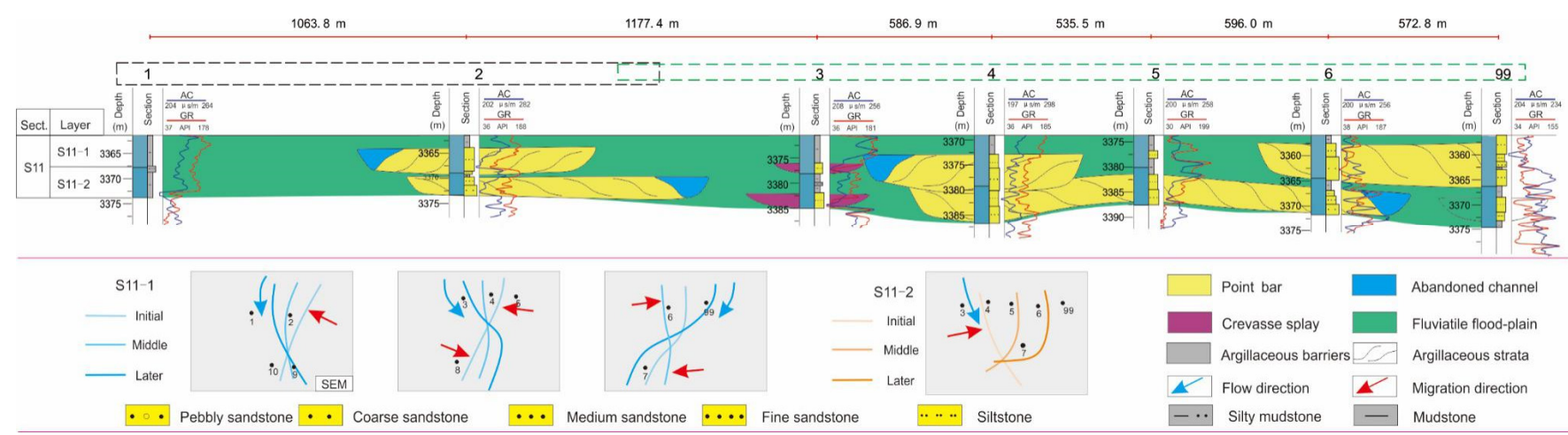

Figure 15. Profile T1 of comprehensive analysis including evolution model of meander bend-based multiple connected core wells which are collected from database in $S_{1}{ }^{1}$ sublayer of Su-X block, Sulige gas field, Ordos Basin, China: migration areas Z1 (green frame), Z2 (black frame).

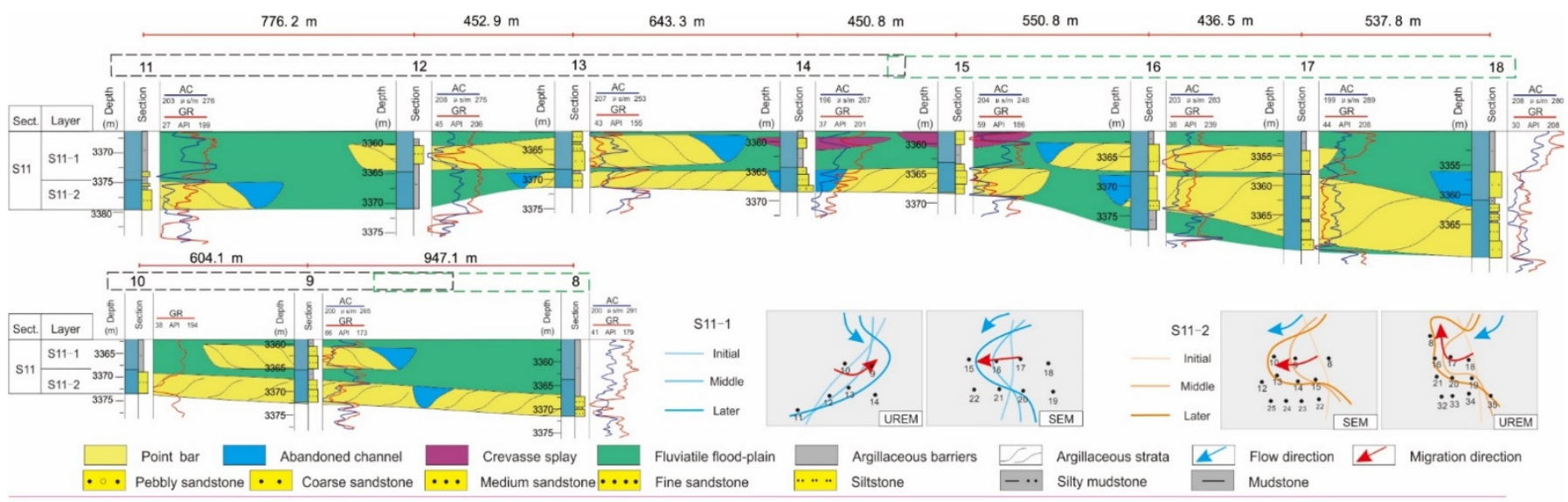

Figure 16. Profile T2 and T3 of comprehensive analysis including evolution model of meander bend-based multiple connected core wells which are collected from database in $\mathrm{S}_{1}{ }^{1}$ sublayer of Su-X block, Sulige gas field, Ordos Basin, China: migration areas Z1 (green frame), Z2 (black frame).

Zone 2: There is a meandering belt in zone 2, and the early sand of well 2 is developed, which belongs to point bar lateral accumulation. Sand was encountered in wells 9, 12, 13 and 14 (Bend e). Sand is developed in wells 9 and 13, which is in the range of point bar lateral accretion. Thin sand is developed in well 12 in the middle stage, which is transformed from floodplain to point bar. Crevasse splay sand is developed in the late stage of well 14, and the channel moves from well 13 to well 14. In the early stage of wells 26 and 27 (Bend f), the sand developed from point bar to floodplain, and the channel migrated from well 27 to well 26. The sand bodies of other wells are undeveloped and belong to the floodplain; The analysis of the anatomy indicate that Bend e migrates with UREM deviating away from the meander belt axis towards the upstream direction and Bend $\mathrm{f}$ migrates with DREM, deviating away from the meander belt axis towards the downstream direction, as shown in the Figures 15-17.

Zone 3: Is downstream from zone 2. Sand is encountered in wells 56, 62 and 63 (Bend g). Early sand is developed in well 56, middle sand is developed in well 63, and sand is developed in well 62, which indicates that the channel migrates from 56 to 63 and then to well 62. The sand of well 67 (Bend h) is developed, which belongs to point bar lateral deposition. The early sand body of well 76 is crevasse splay. Comprehensive analysis shows that Bend g migrates from SEM to DREM and Bend h migrates with UREM. 


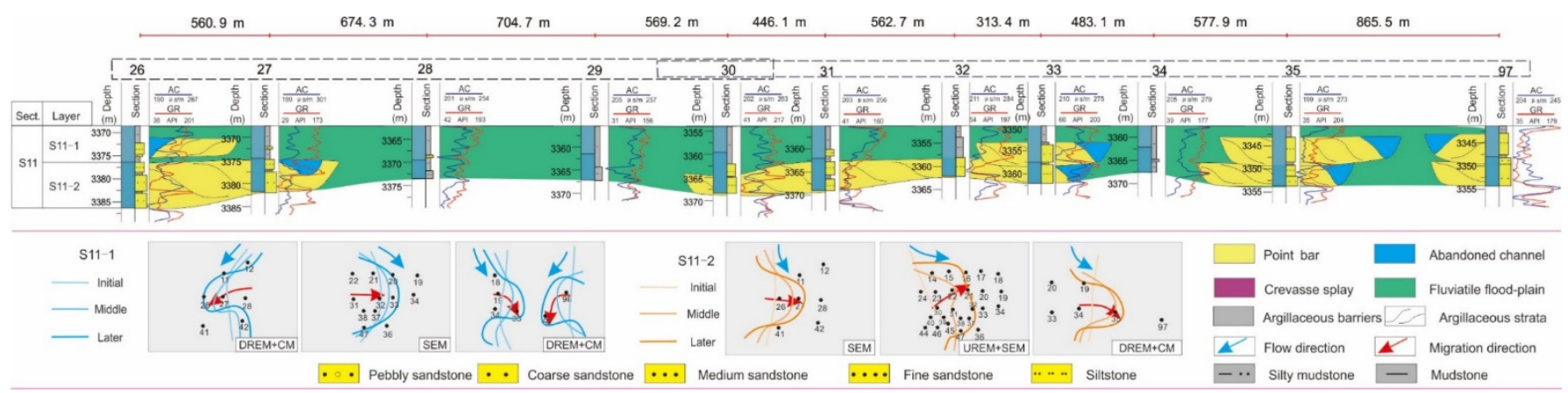

Figure 17. Profile T5 of comprehensive analysis including evolution model of meander bend-based multiple connected core wells which are collected from database in $S_{1}{ }^{1}$ sublayer of Su-X block, Sulige gas field, Ordos Basin, China: migration areas Z2 (black frame), Z4 (gray frame).

Zone 4: Is downstream from zone 1. The sand of well 32 is not developed. The sand of well 33 (Bend d) is developed in the early stage, which is formed by lateral deposition of the point bar. The late stage sand is not developed, which indicates the migration from point bar to abandoned channel. The sand of well 47 is not developed in the early stage, but developed in the late stage, which indicates that the floodplain is transformed into point bar; The early sand of well 52 is not developed, and the later sand is developed, which indicates that it has changed from floodplain to point bar. The early thin sand of well 52 (Bend I) is developed, and the later sand body is thick, which indicates that it has changed from abandoned channel to point bar; Sand is encountered in wells 68 and 74 (Bend J). The early sand is more developed than the later sand in well 68. The sand of well 74 developed in the late stage, while that of well 75 did not, indicating that the channel moved from well 75 to well 74. The results of the anatomy indicate that Bend d migrates with SEM, Bend I migrate with SEM+UREM and Bend J migrates with SEM, as shown in the Figures 14, 17 and 18.

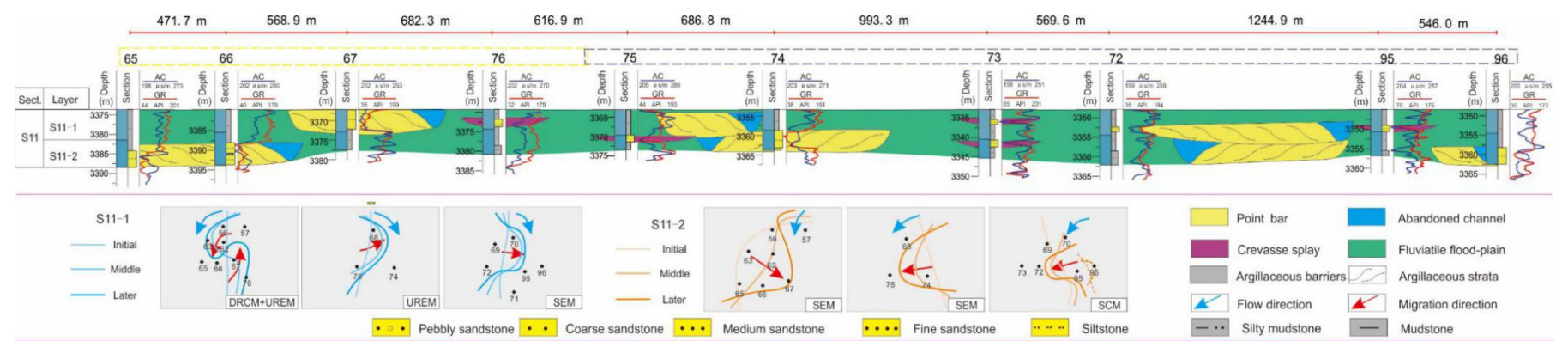

Figure 18. Profile T11 of comprehensive analysis including evolution model of meander bend-based multiple connected core wells which are collected from database in $S_{1}{ }^{1}$ sublayer of Su-X block, Sulige gas field, Ordos Basin, China: migration areas Z3 (yellow frame), Z4(gray frame).

Zone 5: Sand is encountered in wells 71, 87 and 88 . The sand in wells 71 and 88 (Bend $\mathrm{K}$ ) is developed, which is the point bar. Multistage sand is developed in well 87; in the early stage of well 89 (Bend L), the sand is developed, which is point bar lateral deposition, and the overflow sand is developed in the late stage; sand is encountered in wells 85,91 and 92 which are branch channel deposits. The sand in wells 85 and 91 is crevasse splay, and the sand in well 92 (Bend O) is developed in the early stage formed by point bar lateral accumulation.

Zone 6: In well 80 (Bend M), the sand developed in the early stage and did not develop in the late stage, indicating the migration from point bar to floodplain deposit; the sand of well 83 (Bend N) is developed and formed by lateral accretion of the point bar; because there are few wells in Zone 6, it is difficult to determine the migration of the river. Combined with the migration characteristics of the upstream and the characteristics of topography 
and structure, Bend N migrates with SEM, and the channel converged in this Zone, as shown in Figures 14 and 19.

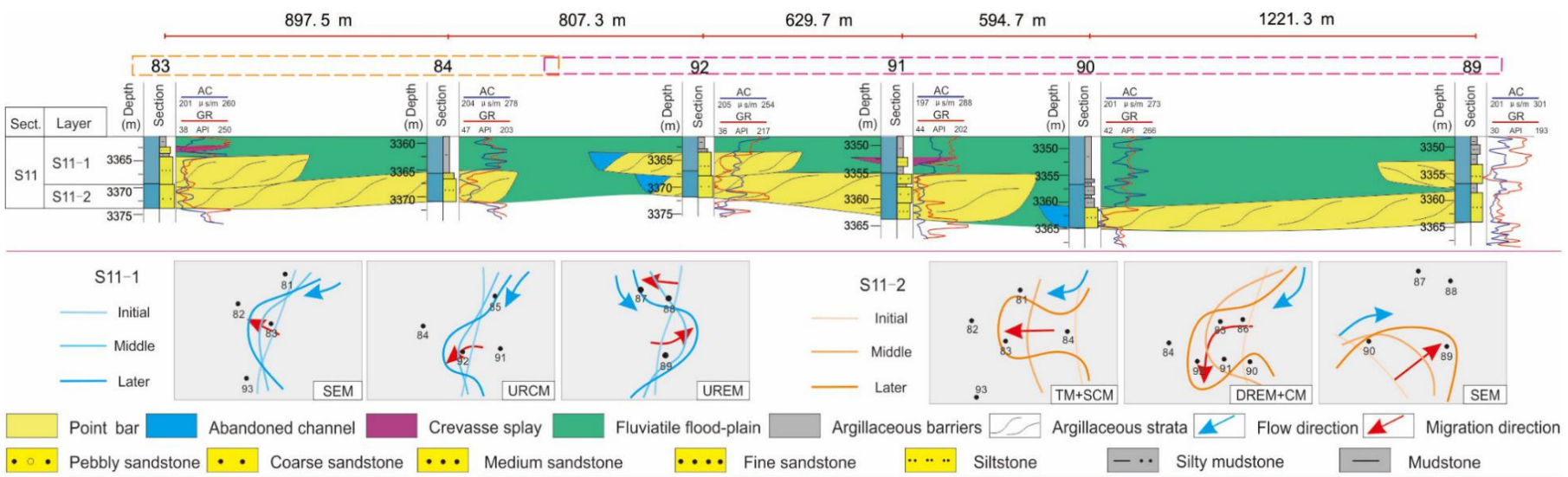

Figure 19. Profile T14 of comprehensive analysis including evolution model of meander bend-based multiple connected core wells which are collected from database in $S_{1}{ }^{1}$ sublayer of Su-X block, Sulige gas field, Ordos Basin, China: migration areas Z5 (red frame), Z6 (orange frame).

The results of anatomy indicate that Bend $\mathrm{K}$ migrates with DREM, Bend L migrates with UREM and Bend O migrates with DREM. The law of the other point bar is inferred, according to the structural landform and hydrodynamic characteristics, as shown in Figures 20 and 21.

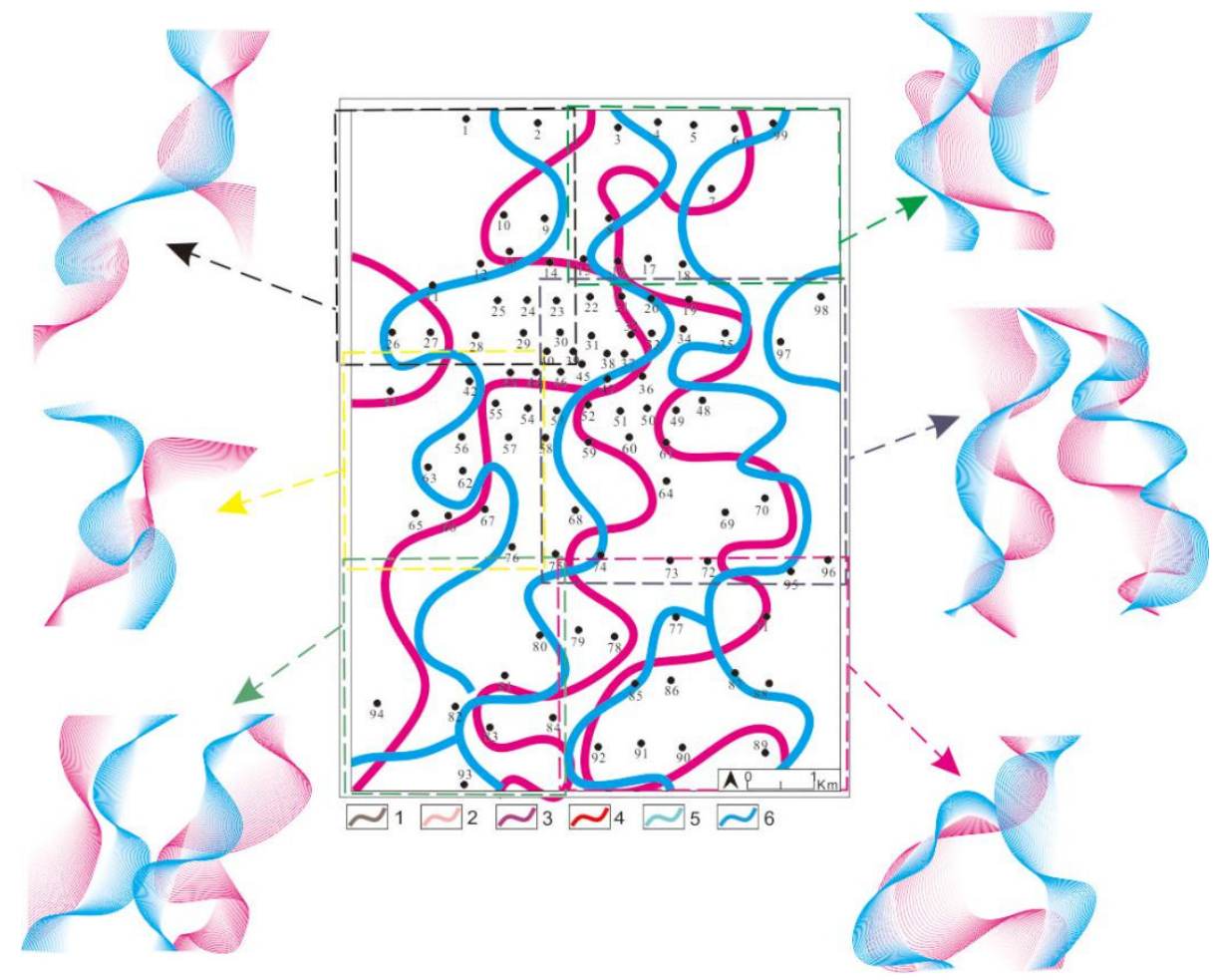

Figure 20. Migration modes of ancient planform of $\mathrm{S}_{1}{ }^{1}$ monolayer in the Sulige gas field of Ordos Basin, China. 


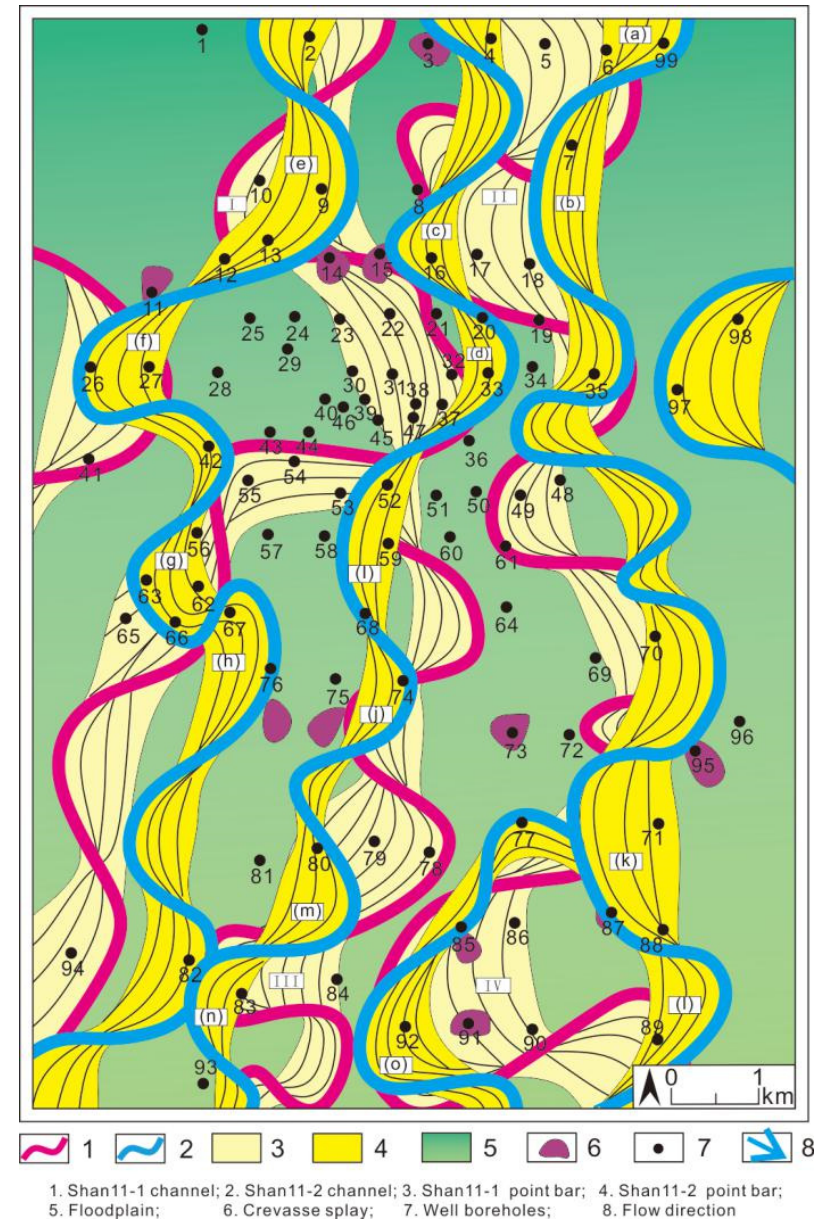

Figure 21. Reconstruction of the complex meandering belt based on the dense network of well data.

\section{Discussion}

\subsection{Migration Characteristics}

Based on the reconstruction methods of the modern Okavango meandering river and the previous migration model, combined with the ancient flow analysis and the track of the center line in the early and late stages, the ancient meandering channel was reconstructed. Combined with the coupling mechanism of the plane-profile characteristics of a meandering river, the channel migration is finely depicted. In the study area, the whole meander belt was mainly formed by the expansion model, followed by the contraction model and, occasionally, the translational migration model. The later channel inherited the evolution of the early channel, and the compound migration model was more common in a single layer (Figure 20). Expansion (Figure 21, Bend b, c, d) increased the curvature and flow path length. The bend apex is away from the meander belt axis and nonlinear migration path with increasing the asymmetrical bend in rotation (Figure 21, Bend f, g, h, o, II). Translation (Figure 21, Bend III) is characterized by the bend apex parallel to the meander belt axis without an obvious change in the sinuosity. Under the conditions of continuous expansion of the channel, the upstream bar is easy to preserve; However, almost all upstream bars will suffer local erosion, resulting in the restriction of the trajectory to the downstream. According to the data of logging, logging and core observation, the abandoned channel and point bar were identified, which clearly showed the strong cutting, diversion and damage of the late channel to the early channel. The complex meandering river belt reveals the evolution process of the ancient channel, with constant cut-off and confluence branching of rivers. The above figure shows the reconstruction of the ancient meandering river belt in $S_{1}{ }^{1}$. The research shows that a single meandering ring can be combined from different profiles, the whole river runs through north-south, and the flow of the whole $S_{1}{ }^{1}$ 
sublayer is discontinuous. The sedimentary characteristics and vertical heterogeneity of channel sandstone are shown on the connecting well profiles, and the sand shows different distribution and superposition forms. It is reasonable to guide the evolution mechanism of the ancient meandering river with the characteristics of modern meandering river, but the accuracy of stratigraphic correlation and anatomy has a certain impact on the reconstruction of the meandering belt. So, the result is uncertainty. At the same time, the dense well area plays an important role in guiding the sparse well area, but the river migration structure in the sparse well area is still uncertain. The sediments of the different meandering rivers are also different. Under the condition of high-energy hydrodynamics, the sediments are characterized by coarse grains, showing weak aggradation; the low energy hydrodynamic condition is opposite. In the composite migration model, the separation and recognition of a single pattern is complex, which also increases the difficulty of river structure fineness and reconstruction. At present, improving the well pattern density could solve the problem.

\subsection{Comparison of Results from Empirical Equations and Actual Reconstruction}

The studied meander belt was characterized by a channel as deep as mean $5.6 \mathrm{~m}$, based on the anatomy of the dense well net, thus, the thickness of buried sand is compacted and corrected. The average burial depth of $\mathrm{S}_{1}{ }^{1}$ is about $3360 \mathrm{~m}$. The authors [60] presented the formula of buried depth and porosity based on the analysis of clay and Hegarty [61] generalized the formula of the thickness (sandstone and mudstone)-buried depth formula. Based on the above empirical relationships, the $5.6 \mathrm{~m}$ thickness of the channel sandstone from almost $3360 \mathrm{~m}$ depth is restored to its original thickness. this value is almost 1.42 times. The empirical formula is compared with the actual reconstruction results:

Formula (1) is from Leeder [62], Formulas (2)-(5) are from Williams [63], Formula (6) is organized by the author, based on Leeder and Williams [62,63]. In the sandstone thickness after compaction correction, seven empirical formulas in the table are used to estimate the relevant parameters of channel scale (Table 1).

Table 1. Empirical equations of estimation of quantitative parameters for meandering channel.

\begin{tabular}{|c|c|c|c|c|c|c|}
\hline \multirow{2}{*}{$\begin{array}{l}\text { Reference } \\
\text { Number }\end{array}$} & \multirow{2}{*}{ Equation } & \multirow{2}{*}{ Units } & \multicolumn{2}{|c|}{$\begin{array}{l}\text { Standard Deviation of } \\
\text { Residuals in Percent }\end{array}$} & \multirow{2}{*}{ Correlation Coefficient } & \multirow{2}{*}{$\begin{array}{c}\text { Applicable } \\
\text { Range (m) }\end{array}$} \\
\hline & & & + & - & & \\
\hline 1 & $\lg W=1.54 \lg \mathrm{D}+0.83$ & $\mathrm{~m}$ & - & - & - & - \\
\hline 2 & $\mathrm{~L}_{\mathrm{m}}=7.5 \mathrm{~W}^{1.12}$ & $\mathrm{~m}$ & 74 & 42 & 0.96 & $1.5 \leq \mathrm{W} \leq 4000$ \\
\hline 3 & $\mathrm{~L}_{\mathrm{b}}=5.1 \mathrm{~W}^{1.12}$ & $\mathrm{~m}$ & 65 & 39 & 0.97 & $1.5 \leq W \leq 2000$ \\
\hline 4 & $\mathrm{~B}=4.3 \mathrm{~W}^{1.12}$ & $\mathrm{~m}$ & 65 & 39 & 0.96 & $1.5 \leq W \leq 4000$ \\
\hline 5 & $\mathrm{R}_{\mathrm{c}}=1.5 \mathrm{~W}^{1.12}$ & $\mathrm{~m}$ & 55 & 35 & 0.97 & $1.5 \leq W \leq 2000$ \\
\hline 6 & $\mathrm{~S}=\mathrm{e}^{0.52 \ln 14 \mathrm{D}^{-0.54}}$ & - & - & - & - & - \\
\hline 7 & $\mathrm{Q}=0.004 \mathrm{e}^{1.61 \operatorname{lnLm}}$ & $\mathrm{m}^{3} / \mathrm{s}$ & - & - & - & - \\
\hline
\end{tabular}

Comparing the two results, the results are basically consistent with the results of the seven empirical formulas (Table 2). Only in Bend III, IV, the actual value is larger (table), which may be because they belong to the composite migration model, the migration process is more complex, which makes the sand thickness obtained from sedimentary data uncertain. Bend $\mathrm{c}$ and $\mathrm{I}$ are SEM, Bend e and bend $\mathrm{h}$ are UREM. Bend $\mathrm{g}$ is DREM. Bend II is $\mathrm{URCM}+\mathrm{SEM}$. Bend III is TM + SCM. Bend IV is DREM + CM. Compared with the single mode, the compound model has a stronger hydrodynamic force, and has the characteristics with upstream bar erosion and the downstream bar superposition. Due to the later river 
erosion, the early point bar is eroded, and the sand body thickness is thinned, which affects the accuracy. In addition, the later river has more stable hydrodynamic characteristics.

Table 2. Comparison of results from empirical equations and actual reconstruction.

\begin{tabular}{|c|c|c|c|c|c|c|c|c|c|c|}
\hline $\begin{array}{l}\text { Bend } \\
\text { Units }\end{array}$ & Methods & $\begin{array}{r}\text { Compacted } \\
\mathbf{m}\end{array}$ & Initial & $\begin{array}{l}W \\
(\mathrm{~m})\end{array}$ & $\begin{array}{l}\mathrm{Lm} \\
(\mathrm{m})\end{array}$ & $\begin{array}{l}\mathrm{Lb} \\
(\mathrm{m})\end{array}$ & $\begin{array}{l}\text { Wm } \\
(\mathrm{m})\end{array}$ & $\begin{array}{l}\mathrm{Rc} \\
(\mathrm{m})\end{array}$ & $\begin{array}{l}\mathrm{S} \\
/\end{array}$ & $\underset{\mathrm{m}^{3} / \mathrm{s}}{\mathrm{Q}}$ \\
\hline \multirow{2}{*}{ c } & Equation & \multirow{2}{*}{4.1} & \multirow{2}{*}{6.15} & 111.5 & 1472.7 & 1001.4 & 844.37 & 294.5 & 2.4 & 504.36 \\
\hline & Actual value & & & 一 & 1718.4 & 1291.8 & 779.1 & 331.8 & 1.4 & - \\
\hline \multirow{2}{*}{ e } & Equation & \multirow{2}{*}{5} & \multirow{2}{*}{7.5} & 151.4 & 2073.9 & 1410.2 & 1189.0 & 414.8 & 2.2 & 875.1 \\
\hline & Actual value & & & - & 2302.6 & 1563.3 & 958.7 & 575.2 & 1.5 & - \\
\hline \multirow{2}{*}{ g } & Equation & \multirow{2}{*}{5.2} & \multirow{2}{*}{7.8} & 160.8 & 2218.9 & 1508.9 & 1272.2 & 443.8 & 2.2 & 975.8 \\
\hline & Actual value & & & - & 2318.2 & 1249.5 & 1140.6 & 373.8 & 2.0 & - \\
\hline \multirow[b]{2}{*}{$\mathrm{h}$} & Equation & \multirow[b]{2}{*}{6} & \multirow{2}{*}{9} & 200.5 & 2840.2 & 1931.3 & 1628.4 & 568.0 & 2.1 & 1451.9 \\
\hline & Actual value & & & - & 2526.2 & 1764.2 & 1413.9 & 557.4 & 1.7 & - \\
\hline \multirow{2}{*}{ I } & Equation & \multirow{2}{*}{3.6} & \multirow{2}{*}{5.4} & 91.3 & 1176.8 & 800.2 & 674.7 & 235.4 & 2.5 & 351.5 \\
\hline & Actual value & & & - & 1849.1 & 1642.6 & 1152.2 & 673.4 & 1.8 & - \\
\hline \multirow{2}{*}{ II } & Equation & \multirow{2}{*}{6} & \multirow{2}{*}{9} & 200.5 & 2840.2 & 1931.3 & 1628.4 & 568.0 & 2.1 & 1451.9 \\
\hline & Actual value & & & - & 2684.3 & 2216.6 & 1688.8 & 543.6 & 2.2 & - \\
\hline \multirow{2}{*}{ III } & Equation & \multirow{2}{*}{4.5} & \multirow{2}{*}{6.75} & 128.7 & 1729.2 & 1175.8 & 991.43 & 345.8 & 2.3 & 653.14 \\
\hline & Actual value & & & - & 2720.6 & 929.05 & 1662.7 & 432.1 & 2.9 & - \\
\hline \multirow{2}{*}{ IV } & Equation & \multirow{2}{*}{4.8} & \multirow{2}{*}{7.2} & 142.2 & 1932.9 & 1314.3 & 1108.1 & 386.5 & 2.2 & 781.34 \\
\hline & Actual value & & & - & 2631.7 & 2091.0 & 1755.9 & 506.3 & 2.6 & - \\
\hline
\end{tabular}

\section{Conclusions}

Based on the previous research $[8,14,28]$ and satellite image survey results, the modern meandering river migration model has eight single models: symmetrical expansion migration (SEM), upstream rotation expansion migration (UREM), downstream rotation expansion migration, contraction migration (SCM), upstream rotation contraction migration (URCM), downstream rotation contraction migration (DRCM), translation migration(TM) and translation rotation migration(TRM). The four compound models of channel morphology are symmetrical expansion + contraction migration $(\mathrm{SE}+\mathrm{CM})$, upstream rotation expansion + contraction migration $(\mathrm{URE}+\mathrm{CM})$, downstream rotation expansion + contraction migration $(\mathrm{DRE}+\mathrm{CM})$, translation rotation + expansion migration $(\mathrm{TR}+\mathrm{EM})$. In the process of river migration, the length and curvature of the river are increasing, and it is easy to develop a cut-off and chute.

The results show that the ancient mean bankfull width (W) is almost $140 \mathrm{~m}$, the average width of a single meander (B) is about $1300 \mathrm{~m}$, the average radius of curvature (R) is about $490 \mathrm{~m}$, the average length of a meander $(\mathrm{Lb})$ is about $1500 \mathrm{~m}$, the average wavelength of a meander $(\mathrm{Lm})$ is about $2300 \mathrm{~m}$, the average sinuosity $(\mathrm{S})$ is almost 2.0, and the mean annual discharge estimated by empirical formula (Q) is about $880 \mathrm{~m}^{3} / \mathrm{s}$. No matter in time scale or space scale, when a multistage channel migrates, the early channel is easily eroded and transformed by the later channel; it is difficult to preserve completely. Channel migration is mainly asymmetric, mainly in the downstream migration model.

The empirical formula and the actual reconstruction results show that the actual anatomy is basically consistent with the empirical formula in the table, which indicates that in order to obtain the real geometric parameters of the ancient meandering channel, it is necessary to correct the sedimentary thickness, otherwise the formula result will be less than the actual value.

This study from the central Ordos Basin is an example of the restoration of an ancient channel belt to demonstrate how the planform evolution of an ancient meandering river can be reconstructed from horizontal and vertical profiles. The reconstruction process is 
affected by many factors. Improving the well pattern density is an effective way to solve the uncertainty.

Author Contributions: Conceptualization, J.Z. and X.Y.; methodology, J.Z. and X.Y.; software, X.Y.; formal analysis, X.Y.; investigation, Y.L. and L.S.; data curation, X.Y.; writing-original draft preparation, X.Y. and Y.L.; writing-review and editing, X.Y. and Y.Z. All authors have read and agreed to the published version of the manuscript.

Funding: This research was funded by [Project funded by China Postdoctoral Science Foundation] grant number [2021M700537].

Institutional Review Board Statement: Not applicable.

Informed Consent Statement: Not applicable.

Data Availability Statement: The data presented in this study are available upon request from the corresponding author.

Conflicts of Interest: The authors declare no conflict of interest.

\section{References}

1. Güneralp, İ.; Abad, J.D.; Zolezzi, G.; Hooke, J. Advances and challenges in meandering channels research. Geomorphology 2012, 163-164, 1-9. [CrossRef]

2. Tooth, S.; Mccarthy, T.S. Controls on the transition from meandering to straight channels in the wetlands of the Okavango Delta, Botswana. Earth Surf. Processes Landf. 2010, 29, 1627-1649. [CrossRef]

3. Gumbricht, T.; Mccarthy, J.; Mccarthy, T.S. Channels, wetlands and islands in the Okavango Delta, Botswana, and their relation to hydrological and sedimentological processes. Earth Surf. Processes Landf. 2010, 29, 15-29. [CrossRef]

4. Abad, J.; Frias, C.; Konsoer, K.; Best, J.; Garcia, M.H. Modulation of the flow structure by progressive bed forms in the meandering Wabash River. In Proceedings of the 7th International Conference on Fluvial Hydraulics, River Flow 2014, Lausanne, Switzerland, 3-5 September 2014.

5. Motta, D.; Abad, J.D.; Langendoen, E.J.; Garcia, M.H. The effects of floodplain soil heterogeneity on meander planform shape. Water Resour. Res. 2012, 48, 17. [CrossRef]

6. Schumm, S.A. Sinuosity of alluvial rivers on the Great Plain. Geol. Soc. Am. Bull. 1963, 74, 1089-1100. [CrossRef]

7. Daniel, J.F. Channel movement of meandering Indiana streams. In US Geological Survey Professional Paper 732-A; US Geological Survey, Water Resources Division: Reston, VA, USA, 1971.

8. Hickin, E.J. The development of meanders in natural river-channels. Am. J. Sci. 1974, 274, 414-442. [CrossRef]

9. Brice, J.C. Evolution of meander loops. Geol. Soc. Am. Bull. 1974, 85, 581-586. [CrossRef]

10. Hooke, J.M. Change in river meanders: A review of techniques and results of analyses. Prog. Phys. Geogr. 1984, 8, 473-508. [CrossRef]

11. Hooke, J.M. River meander behaviour and instability: A framework for analysis. Trans. Inst. Br. Geogr. 2003, 28, 238-253. [CrossRef]

12. Gutierrez, R.; Abad, J.D.; Choi, M.; Montoro, H. On the morphodynamics of free meanders confluences at the Upper Amazon Basin. Geomorphology 2014, 220, 1-14. [CrossRef]

13. Schwendel, A.C.; Nicholas, A.P.; Aalto, R.E.; Smith, G.H.; Buckley, S. Interaction between meander dynamics and floodplain heterogeneity in a large tropical sand-bed river: The Rio Beni, Bolivian Amazon. Earth Surf. Processes Landf. 2015, 40, 2026-2040. [CrossRef]

14. Shan, J.F.; Lin, Z.P.; Chen, L.; Zhang, B.; Fang, S.X.; Yan, X.; Fang, W.W.; Xie, L.L.; Liu, B.; Zhang, L. Reconstruction of meandering paleo-channels using dense well data, Daqing Oil Field, Songliao Basin, China. Pet. Sci. 2018, 15, 722-743. [CrossRef]

15. Davies, T.R.H.; Tinker, C. Characteristics of regular stream meanders. In Proceedings of the Conference on Modern and Ancient Fluvial Systems, University of Keele, Keele, UK, September 1981.

16. Johannesson, H.; Parker, G. Linear theory of river meanders. In River Meandering; Ikeda, S., Parker, G., Eds.; AGU: Washington, DC, USA, 1989; pp. 181-214.

17. Abad, J.D.; García, M.H. RVR Meander: A toolbox for re-meandering of channelized streams. Comput. Geosci. 2006, 32, 92-101. [CrossRef]

18. Frascati, A.; Lanzoni, S. Morphodynamic regime and long-term evolution of meandering rivers. J. Geophys. Res. 2009, 114, F02002. [CrossRef]

19. Neal, A. Ground penetrating radar and its use in sedimentology: Principles, problems and progress. Earth-Sci. Rev. 2004, 66, 261-330. [CrossRef]

20. Schrott, L.; Sass, O. Application of field geophysics in geomorphology: Advances and limitations exemplified by case studies. Geomorphology 2008, 93, 55-73. [CrossRef]

21. Słowik, M. Holocene evolution of meander bends in lowland river valley formed in complex geological conditions (the Obra River, Poland). Geogr. Ann. Ser. A Phys. Geogr. 2014, 96, 61-81. [CrossRef] 
22. Słowik, M. The influence of meander bend evolution on the formation of multiple cutoffs: Findings inferred from floodplain architecture and bend geometry. Earth Surf. Processes Landf. 2015, 41, 626-641. [CrossRef]

23. Cassiani, G.; Bellizia, E.; Fontana, A.; Boaga, J.; D'Alpaos, A.; Ghinassi, M. Geophysical and Sedimentological Investigations Integrate Remote-Sensing Data to Depict Geometry of Fluvial Sedimentary Bodies: An Example from Holocene Point-Bar Deposits of the Venetian Plain (Italy). Remote Sens. 2020, 12, 2568. [CrossRef]

24. Kasvi, E.; Vaaja, M.; Kaartinen, H.; Kukko, A.; Jaakkola, A.; Flener, C.; Hyyppä, H.; Hyyppä, J.; Alho, P. Sub-bend scale flow-sediment interaction of meander bends-A combined approach of field observations, close-range remote sensing and computational modelling. Geomorphology 2015, 238, 119-134. [CrossRef]

25. Brice, J.C. Lateral migration of the Middle Sacramento River, California. In US Geological Survey Report WRD/WR1-77/052; US Geological Survey, Water Resources Division: Reston, VA, USA, 1977.

26. Laczay, I.A. Channel pattern changes of Hungarian river: The example of the Hernad River. In River Channel Changes; Gregory, K.J., Ed.; John Wiley: Chichester, UK, 1977; pp. 184-192.

27. Thorne, C.R.; Lewin, J. Bank processes, bed material movement and planform development in a meandering river. In Adjustments of the Fluvial System; Rhodes, D.D., Williams, G.P., Eds.; George Allen and Unwin: London, UK, 1979; pp. 117-137.

28. Bluck, B.J. Sedimentation in the meandering River Endrick. Scott. J. Geol. 1971, 7, 93-138. [CrossRef]

29. Cuevas Martinez, J.L.; Cabrera, L.; Marcuello, A.; Arbues, P.; Marzo, M.; Bellmunt, F. Exhumed channel sandstone networks within fluvial fan deposits from the Oligo-Miocene Caspe Formation, South-east Ebro Basin (North-east Spain). Sedimentology 2010, 57, 162-189. [CrossRef]

30. Ielpi, A.; Ghinassi, M.; Mountney, N. Planform architecture, stratigraphic signature and morphodynamics of an exhumed Jurassic meander plain (Scalby Formation, Yorkshire, UK). Sedimentology 2014, 61, 1923-1960. [CrossRef]

31. Jackson, R.G., II. Depositional model of point bars in the Lower Wabash River. J. Sed. Petrol. 1976, 46, 579-594.

32. Nanson, G.C. Point bar and floodplain formation of the meandering Beatton River, northeastern British Columbia, Canada. Sedimentology 1980, 27, 3-29. [CrossRef]

33. Gibling, M.R.; Rust, B.R. Alluvial ridge-and-swale topography: A case study from the Morien Group of Atlantic Canada. Int Assoc. Sedimentol. Spec. Publ. 1993, 17, 133-150.

34. Smith, D.G.; Hubbard, S.M.; Lavigne, J.R.; Leckie, D.A.; Fustic, M. Stratigraphy of counter-point-bar and eddy-accretion deposits in low-energy meander belts of the Peace-Athabasca Delta, northeast Alberta, Canada. SEPM Spec. Publ. 2011, 97, 143-152.

35. Zhang, Z.; Sun, K.; Yin, J. Sedimentology and sequence stratigraphy of the Shanxi Formation (Lower Permian) in the northwestern Ordos Basin, China: An alternative sequence model for fluvial strata. Sediment. Geol. 1997, 112, 123-136. [CrossRef]

36. Xiao, H.P. Depositional System and Favorable Reservoir of Shanxi Formation-He 8 Member in Ordos Basin; China University of Geosciences: Beijing, China, 2020. (In Chinese)

37. Cao, Z.H. The Basic Geological Characteristics of the Daniudi Gas Field in Ordos Basin. J. Southwest Pet. Inst. 2005, 27, 17-22. (In Chinese with English Abstract)

38. Dou, W.T.; Hou, M.C.; Dong, G.Y. Provenance Analysis of the Upper Paleozoic Shanxi to Lower Shihezi Formations in North Ordos Basin. Nat. Gas Ind. 2009, 29, 25-28. (In Chinese with English Abstract)

39. Wang, H. Atlas of the Palaeogeography of China; Cartographic Publishing House: Beijing, China, 1985.

40. Wang, C.Y.; Wang, Z.C.; Wang, J.L.; Bao, Y.; Hu, X.M. Reconstruction of paleo river systems and distribution of sedimentary facies of Shanxi and lower Shihezi formations in southern Ordos basin. J. China Univ. Min. Technol. 2008, 18, 241-244. [CrossRef]

41. Chen, H.D.; Li, J.; Zhang, C.G.; Cheng, L.X.; Cheng, L.J. Discussion of sedimentary environment and its geological enlightenment of Shanxi Formation in Ordos Basin. Acta Petrol. Sin. 2011, 27, 2213-2229. (In Chinese)

42. Jiang, Z.X.; Xu, J.; Wang, G.T. The discovery and significance of a sedimentary hiatus with in the Carboniferous Taiyuan Formation, northeastern Ordos Basin, China. AAPG Bull. 2012, 96, 1173-1195. [CrossRef]

43. Liu, R.E.; Xiao, H.P.; Fan, L.Y.; Zhang, C.L.; Hao, A.S.; Liao, W.D. A depositional mode of flood-induced braided river delta in Permian of Ordos Basin. Acta Pet. Sin. 2013, 34 (Suppl. 1), 120-127. (In Chinese)

44. Shen, Y.L.; Guo, Y.H.; Li, Z.F. Sedimentary facies of the Shanxi Formation and Member 8 of Xiashihezi Formation of Permian in Suligemiao area, Ordos Basin. J. Palaeogeogr. 2006, 8, 53-62. (In Chinese)

45. Guo, W.; Liu, H.L.; Xue, H.Q.; Lan, Z.L.; Tang, X.Q. Depositional facies of Permian Shanxi Formation gas shale in the northern Ordos Basin and its impact on shale reservoir. Acta Geol. Sin. 2015, 89, 931-941. (In Chinese) [CrossRef]

46. Yang, J.J.; Fei, X.G. Natural Gas Geology in China Vol. 4: Ordos Basin; Petroleum Industry Press: Beijing, China, 1996.

47. Sun, C.R. Study on Sedimentary Facies and Geochemistry of Trace Elements of Carboniferous-Permian Shale in the Eastern Ordos Basin; China University of Geosciences: Beijing, China, 2017.

48. Shanley, K.W.; McCabe, P.J. Perspectives on the sequence stratigraphy of continental strata. AAPG Bull. 1994, 78, 544-568.

49. Wright, V.P.; Marriott, S.B. The sequence stratigraphy of fluvial depositional systems: The role of floodplain sediment storage. Sediment. Geol. 1993, 86, 203-210. [CrossRef]

50. Zhao, Z.Y.; Liu, G.D.; Sun, M.L.; Lu, W. Discussion on Types of Upper Paleozoic Gas Reservoirs in Ordos Basin. Geoscience 2010, 24, 703-708. (In Chinese)

51. Dai, J.X. Giant Coal-Derived Gas Fields and Their Gas Sources in China; Science Press: Beijing, China, 2014.

52. Bata, T.; Parnell, J.; Bowden, S.; Boyce, A.; Leckie, D. Origin of heavy oil in Cretaceous petroleum reservoirs. Bull. Can. Petrol. Geol. 2016, 64, 106-118. [CrossRef] 
53. Li, Y.; Zhang, J.L.; Xu, Y.H.; Chen, T.; Liu, J.S. Improved understanding of the origin and accumulation of hydrocarbons from multiple source rocks in the Lishui Sag: Insights from statistical methods, gold tube pyrolysis and basin modeling. Mar. Pet. Geol. 2021, 134, 105361. [CrossRef]

54. Harms, J.C.; Southard, J.B.; Spearing, D.R.; Walker, R.G. Depositional Environments as Interpreted from Primary Sedimentary Structures and Stratification Sequences. In SEPM Short Course No. 2 Lecture Notes; Society of Economic Paleontologists and Mineralogists: Dallas, TX, USA, 1975; p. 161.

55. Harms, J.C.; Southard, J.B.; Walker, R.G. Structures and Sequences in Clastic Rocks. In SEPM Short Course No. 9 Lecture Notes; Society of Economic Paleontologists and Mineralogists: Calgary, AB, Canada, 1982; p. 250.

56. Collinson, J.D.; Mountney, N.P.; Thompson, D.B. Sedimentary Structures, 3rd ed.; Terra Publishing: Harpenden, UK, 2006 ; p. 292.

57. Ghinassi, M.; Nemec, W.; Aldinucci, M.; Nehyba, S.; Özaksoy, V.; Fidolini, F. Planform evolution of ancient meandering rivers reconstructed from longitudinal outcrop sections. Sedimentology 2014, 61, 952-977. [CrossRef]

58. Zhang, C.M.; Yin, T.J.; Yu, C.; Ye, J.G.; Du, Q.L. Reservoir Architectural Analysis of Meandering Channel Sandstone in the Delta Plain Based on the Depositional Process. Acta Sedimentol. Sin. 2013, 31, 653-662.

59. Yue, D.L. The Study on Architecture Analysis and Remaining Oil Distribution Patterns of Meandering River Reservoir; China University of Petroleum: Beijing, China, 2006.

60. Magara, K. Compaction and Fluid Migration in Cretaceous Shales of Western Canada; Paper 72-18; Geological Survey of Canada: Ottawa, ON, Canada, 1973; Volume 111, p. 360.

61. Hegarty, K.A.; Weissel, J.K.; Mutter, J.C. Subsidence history of Australia's southern margin: Constraints on basin models. AAPG Bull. 1988, 72, 615-633.

62. Leeder, M.R. Fluviatile fining-upwards cycles and the magnitude of palaeochannels. Geol. Mag. 1973, 110, 265-276. [CrossRef]

63. Williams, G.P. River meanders and channel size. J. Hydrol. 1986, 88, 14-164. [CrossRef] 